This is a conditionally accepted version. The final version can be found at: https://doi.org/10.2308/accr-51555

\title{
Unprofitable Affiliates and Income Shifting Behavior
}

\author{
Lisa De Simone \\ Stanford Graduate School of Business \\ Kenneth J. Klassen \\ University of Waterloo \\ Jeri K. Seidman \\ McIntire School of Commerce, University of Virginia
}

April 2016

Income shifting from high-tax to low-tax jurisdictions is considered a primary method of reducing worldwide tax burdens of multinational firms. Extant research generally makes the high-tax and low-tax distinctions using statutory or aggregated tax rates. However, current losses also affect income-shifting incentives. We extend prior approaches to allow for the inclusion of unprofitable affiliates and test whether the unexpected profit of unprofitable affiliates deviates from the negative association with tax incentives observed in profitable affiliates. Results suggest that multinational firms alter the distribution of reported profits to take advantage of losses. Our point estimate for profitable affiliates implies that an increase of one standard deviation in the tax rate incentives of an affiliate with average return on assets of 13.3 is associated with a lower return on assets of 0.5 percentage points. The same tax incentive of an unprofitable affiliate is associated with an increase in its return on assets of approximately 0.7 percentage points, holding assets, labor, productivity and other factors constant. We further document a larger responsiveness to rates between profitable and unprofitable affiliates in hightax jurisdictions, consistent with predictions.

Keywords: transfer pricing, income shifting, losses

The authors appreciate helpful discussions with Jennifer Blouin and Leslie Robinson, as well as comments from Mary Barth, Daniel Collins, Cristi Gleason, Michelle Hanlon, Jost Heckemeyer, Daniel Lynch, Ed Maydew, Edmund Outslay, Kathy Petroni, Richard Sansing, Casey Schwab, Bridget Stomberg, Erin Towery, Benjamin Whipple, two anonymous reviewers, and workshop participants at the University of Georgia, the University of Iowa, Michigan State University, the Ohio State University, the Stanford Graduate School of Business, the EIASM $4^{\text {th }}$ Workshop on Current Research in Taxation, the 2014 Stanford Accounting Summer Camp, the Tax Policy and the Activities of Multinational Firms Conference at Eberhard Karls Universität Tübingen, and the University of Texas/University of Waterloo International Tax Symposium. The authors are thankful for financial support from the McCombs Research Excellence Fund and the McCombs Supply Chain Management Center of Excellence. 


\section{INTRODUCTION}

Prior research in accounting, finance, and economics finds that firms undertake a strategy of shifting income out of high-tax jurisdictions into low-tax jurisdictions, thus reporting lower profit in high-tax affiliates and higher profit in low-tax affiliates. ${ }^{1}$ In a multinational firm with only profitable affiliates, this shifting strategy results in tax savings equal to the dollars of income shifted times the rate differential between the affiliates, net of any costs.

Researchers generally determine intra-firm tax incentives using either the statutory tax rate or an aggregated effective tax rate. These methods mask an alternative tax-saving recipient of shifted income: an unprofitable, or loss, affiliate. Ignoring the potential benefit of loss carryback, a loss affiliate potentially becomes a temporary, low-tax-rate affiliate because it can have a marginal tax rate much lower than the statutory tax rate. As a result, a firm may shift less income out of an affiliate with a loss than would be expected if the affiliate were profitable. With more aggressive tax planning, a firm may even shift income from profitable affiliates into loss affiliates, reporting lower profit in the profitable affiliates and smaller losses in the loss affiliates.

An income shifting strategy that exploits the lower tax rates of loss affiliates is costly. Efficient transfer pricing strategies can be expensive to put in place and thus are often set over a multi-year period. Moving income to benefit from a loss affiliate necessitates new transactions, re-characterizing the nature of existing transactions, or reorganizing the global supply chain. ${ }^{2}$ Each of these requires creation of supporting documentation, procurement of professional services/advice, and/or a reduction in the probability of sustaining a position on audit. Further,

\footnotetext{
${ }^{1}$ See for example, Collins, Kemsley and Lang (1998); Klassen, Lang and Wolfson (1993); Desai and Dharmapala (2006); Huizinga and Laeven (2008); Weichenrieder (2009); Klassen and Laplante (2012); Dharmapala and Riedel (2013); Dharmapala (2014); and Dyreng and Markle (2015).

${ }^{2}$ Transfer pricing is the price multinational groups set for intercompany transfers of intangible goods, services, rights to exploit intellectual property, and debt (Singh and Mathur 2013). Transfer pricing is an important mechanism by which multinational groups shift income across jurisdictions in response to tax incentives. We acknowledge that we do not directly observe intercompany transfers but rather follow the literature cited above that infers income-tax motivated transfer prices from the relation between tax incentives and unexpected profit.
} 
affiliate losses may be short lived as the affiliate often returns to profitability or ceases operation. ${ }^{3}$ Finally, though firms must consider both the current and the projected tax-paying status of each affiliate when they implement an income shifting strategy, predicting the future tax-paying status is more difficult for loss affiliates than for profitable affiliates. Whether the tax savings from this strategy outweigh the costs necessary to deviate from the "traditional" high-tax to low-tax income shifting strategy examined in prior work is an empirical question.

Our paper uses affiliate-level data on multinational firms to explore responses to the income shifting incentives generated by loss affiliates. ${ }^{4}$ To include loss affiliates in the traditional logged Cobb-Douglas profit prediction model, we measure profitability as return on assets plus one. ${ }^{5}$ We estimate a model that specifies affiliate profitability as a function of labor, assets, productivity, age, macroeconomic and industry-level shocks, and tax-related factors on a sample that includes loss affiliates.

We first examine the relation between affiliates' pre-tax earnings and the composite tax incentive variable, $C$, developed by Huizinga and Laeven (2008). The relation between profit and tax incentives is expected to be negative in the presence of income shifting (Hines and Rice, 1994). Consistent with prior literature using only profitable affiliates, we estimate an increase of one percent in a profitable affiliate's composite tax incentive is associated with a 0.75 percent decrease in reported profitability on the mean ROA.

Despite potential costs to altering the transfer pricing strategy to exploit losses, we hypothesize that this relation will be less negative, or even positive, for affiliates with losses.

\footnotetext{
${ }^{3}$ It is possible for a multinational to continue to operate an affiliate with structural losses due to strategic or other reasons. However, one would expect this to be rare because structural losses are costly to the global firm.

${ }^{4}$ Consistent with many income shifting studies, we use reported book (financial statement) income as a proxy for taxable income (Claessens and Laeven 2004; De Simone 2016; Dharmapala and Riedel 2013; Hines and Rice 1994; Huizinga and Laeven 2008; Klassen, Lang and Wolfson 1993; Klasssen and Laplante 2012; Markle 2015).

${ }^{5}$ Claessens and Laeven (2004) also adopt this transformation of the traditional logged Cobb-Douglas profit prediction model in order to include unprofitable banks in their cross-jurisdictional study of bank competition. We examine the effect of this choice below.
} 
Consistent with that expectation, we estimate a positive coefficient on the interaction of the composite tax incentive variable and an indicator for current period loss. Further, we estimate that an increase of one percent in the composite tax incentive of loss affiliates is associated with a 1.24 percent increase in profitability on average. Thus, we show that the overall relation between tax incentives and pre-tax earnings for loss affiliates is positive, consistent with a strategy of shifting profits to loss affiliates, on average.

However, we note a couple of limitations with the composite tax variable. First, it requires information on all affiliates of a multinational corporation to be complete. Second, it is especially susceptible to omitted information about low-tax affiliates, such as loss or tax haven affiliates. Given these concerns, we repeat our above analysis using the statutory tax rate and estimate similar results. Specifically, our point estimates of semi-elasticities imply that on average a one percent increase in the statutory tax rate of a profitable affiliate is associated with a 0.62 percent decrease reported profitability, and the same change in the statutory tax rate for a loss affiliate is associated with a 0.70 percent increase in reported profitability. These two sets of tests provide support for our hypothesis that the reported profit of loss affiliates exhibits a different relation with tax incentives than does the reported profit of profitable affiliates.

We next consider the subset of affiliates we expect to alter their transfer prices the most. In cases where the costs are very high or the benefits are very low, the firm's global tax benefits of altering the income shifting will not exceed the costs. A low-tax loss affiliate is expected to receive shifted income under both the traditional and "shift-to-loss" strategies. ${ }^{6}$ Incentives to receive additional shifted income will result in a small benefit to the global firm. A loss affiliate in a high tax-rate country, in contrast, is expected to provide shifted income in a traditional

\footnotetext{
${ }^{6}$ We use the term "shift-to-loss" to indicate transfer pricing that is altered in the presence of, or upon the expectation of, a loss affiliate. As described above, a shift-to-loss strategy could involve shifting profit from a profitable affiliate to a loss affiliate or shifting less profit out of an affiliate that is expected to experience a loss.
} 
strategy but receive shifted income in a shift-to-loss strategy. Providing an additional recipient of shifted income will provide a larger benefit to the global firm. Comparing reported profit under a shift-to-loss strategy with reported profit under a traditional strategy, we expect that the strengthening of existing incentives in low-tax affiliates will be less disruptive (less costly) but also less beneficial than the sign change of incentives in high-tax affiliates. Thus, we hypothesize that the level of the underlying tax rate alters the magnitude of the relation between unexpected profit and the tax incentive for loss affiliates. We separate affiliates by the magnitude of their jurisdictions' statutory tax rate and test whether the difference in responsiveness of unexpected losses to the tax incentive is more pronounced for loss affiliates in high-tax jurisdictions than those in low-tax jurisdictions. Results confirm that the responsiveness of unexpected profits to the tax incentives of low-tax loss affiliates are significantly less negative than that of low-tax profitable affiliates, and the difference in responsiveness between profitable and loss affiliates is even greater for affiliates located in high-tax rate jurisdictions. That the difference in response between profitable and loss affiliates is increasing in the jurisdictions' tax rates supports our second hypothesis.

Finally, we explore in more detail the effect of loss affiliates within a corporate group. Specifically, we estimate the relation between profitability and tax incentives for three groups of affiliate-years based on both the profit status of the affiliate and of their affiliated group members. The three groups are profitable affiliates in firms in which all affiliates are profitable, profitable affiliates in firms in which some affiliates report losses, and loss affiliates. As above, we estimate an overall positive coefficient on the interaction between loss and tax incentives for loss affiliates. We further estimate that profitable affiliates with at least one loss affiliate in their affiliated group report profit that is less negatively related to their tax incentives than do profitable affiliates in an entirely profitable affiliate group. This is consistent with firms altering 
their traditional response to income-shifting incentives in the presence of loss-making affiliates and provides further evidence that the existence of loss affiliates disrupts the traditional pattern of income shifting.

This paper is in the spirit of Gramlich, Limpaphayom, and Rhee (2004) and Onji and Vera (2010), who both study income shifting among Japanese keiretsu members. Both papers document a lower incidence of losses in affiliated members relative to unaffiliated members, suggesting affiliated groups band together to save keiretsu-level income taxes. ${ }^{7}$ We contribute to this literature by using a cross-border setting that allows us to exploit variation in tax rates and heterogeneous affiliate tax characteristics to incorporate loss affiliates into a composite tax rate variable. Importantly, we are the first to use a cross-border sample to test tax-motivated shift-toloss income shifting and thus are the first to document that the presence of loss affiliates affects the reported profitability of affiliated firms.

This study informs policy makers who, in light of increased multinational income shifting and the recent economic downturn, are debating how to curb tax base erosion and profit shifting (OECD, 2013; Saint-Amans and Russo, 2013). Our results suggest that, upon exam, revenue authorities consider both affiliates in low-tax jurisdictions and affiliates in jurisdictions or industries experiencing losses as potential recipients of the profits they hope to recover. Also, our study provides evidence that firms will respond to even temporary tax-minimizing opportunities despite non-trivial costs, which contributes to policy maker analyses of altering tax policies targeted at multinational corporations, such as repatriation tax holidays, temporary tax incentives for foreign direct investors, and patent boxes.

\footnotetext{
${ }^{7}$ This result is also consistent with risk sharing if profitable affiliates absorb unfavorable outcomes of loss members, rather than profitable members using the tax losses of unprofitable members. Kim and Yi (2006) document earnings management in affiliated Korean firms ("chaebols"), consistent with risk-sharing-motivated income shifting.
} 
Furthermore, our results inform public economists regarding the semi-elasticity of reported income to changes in tax rates. Our paper suggests that, by using samples of only profitable affiliates, previous estimates of the magnitudes of income shifting in response to tax rate changes should be considered a lower bound. ${ }^{8}$ Some shifting by profitable affiliates goes to loss affiliates, rather than to low-tax profitable affiliates. Additionally, because losses are expected to be transitory in general (Hayn, 1995; Frankel and Litov, 2009), the incentives to shift to a loss affiliate would be less affected than by a change in the statutory tax rate. Thus, previous estimates generated using only profitable affiliates include both these the muted responses to tax rate differences. Our analysis demonstrates that the semi-elasticity for profitable affiliates increases from 0.81 to 1.50 when the presence of loss affiliates is fully considered.

Our results also inform researchers who should consider the impact of this alternative tax-reducing transfer pricing strategy. Many income shifting studies use aggregated affiliate profits and losses (i.e., consolidated financial statement data), which confounds the two types of income shifting strategies by combining a number of potentially-conflicting transfer pricing incentives. Other income shifting studies restrict their sample to profitable observations. ${ }^{9}$ The removal of loss affiliates does not fully address the concern, though, because the effect of shifting to these affiliates is also reflected in the responsiveness of profitable affiliates to their tax incentives. Our supplemental tests show a significant difference in response between profitable affiliates without a loss affiliate and profitable affiliates with a loss affiliate.

Finally, this study deepens our understanding of the income shifting practices of multinational firms. Examining a new and economically significant income shifting setting helps

\footnotetext{
${ }^{8}$ Results in the concurrent working paper Hopland, Lisowsky, Mardan and Schindler (2014), who examine levels of payments between affiliated firms in Norway, also support an understatement of sensitivity of transfer prices to tax rate changes in prior literature.

${ }^{9}$ For example, Power and Silverstein (2007) excludes unprofitable US parents and Blouin, Robinson and Seidman (2015), De Simone (2016), and Markle (2015) exclude unprofitable affiliates.
} 
answer the call in Shackelford and Shevlin (2001) to increase our ability to explain and predict income-shifting strategies. Additionally, Hanlon and Heitzman (2010) point out that researchers understand little about how the existence of a loss affects firm behavior. Our results suggest that firms alter their transfer prices to take advantage of losses and that affiliates in high-tax jurisdictions experience a more significant alteration than do affiliates in low-tax jurisdictions.

\section{BACKGROUND AND RELATED LITERATURE}

\section{Income Shifting Background}

The most effective income shifting strategies employ two components in concert with each other: an operational decision and an accounting decision. The operational decision entails tax-efficiently structuring the firm's global supply chain to strategically locate the affiliated parties to major intercompany transactions. As such, multinationals often locate high-return assets and activities in low-tax jurisdictions and low-return activities in high-tax jurisdictions. ${ }^{10}$

Further, multinationals have incentives to choose prices for these intercompany transactions that optimize the worldwide tax burden of the firm; this represents the accounting decision component. Transfer pricing guidelines for income tax reporting are established by the OECD, and have been adopted in some form by most European countries. These regulations prescribe that for the purposes of calculating taxable income, any intercompany prices for goods, services and intangibles should be those that would have been realized if the parties were unrelated, known as the "arm's length principle" (OECD, 2010). However, these arm's length prices can be difficult to observe, especially for services, unique intangibles, and unusual or

\footnotetext{
${ }^{10}$ Examples of high-return activities include the research and development of unique intangibles. Examples of lowreturn activities include contract manufacturing and limited-risk distribution. Interestingly, the OECD explicitly excludes these types of tax-motivated location decisions from its definition of base erosion and profit shifting, or BEPS (OECD 2015, 42). They define profit shifting as the movement of taxable profits away from the jurisdiction in which the economic activity generating those profits are located.
} 
unfinished products (PWC, 2006). This inability to always find exact market price matches for intercompany transactions leaves multinational entities some discretion in setting transfer prices. Further, although many multinationals strive to appropriately price a transaction during the course of the year, they can also make so-called "topside adjustments" to these prices after the financial books have been closed but prior to the filing of the tax return. ${ }^{11}$ Thus, the accounting decision for how and when to set the transfer price of an intercompany transaction is flexible and relatively nimble when compared to the operational decision.

When a multinational firm anticipates an affiliate will earn a loss, the multinational has a number of options to consider. First, the affiliate could simply report the loss as earned under its existing transfer-pricing strategy. If its jurisdiction allows loss carryback and it was profitable during the allowed carryback period, the reported loss will generate an immediate refund. If its jurisdiction does not allow loss carryback (or if it was not profitable during the allowed carryback period) but does allow loss carryforward, the reported loss will generate tax savings in the future if the affiliate returns to profitability. If the jurisdiction of the reported loss does not allow loss carryback or loss carryforward, the reported loss generates no tax benefit for the multinational firm. Thus, both the adjustment costs and the benefits are lowest under this option.

Second, in certain jurisdictions, the multinational firm may be able to consolidate across borders to allow a loss in one jurisdiction to offset profit in another jurisdiction. For example, France and Denmark have long-standing cross border consolidation policies with other EU member states. However, due to system limitations such as long lock-in periods and the inability

\footnotetext{
${ }^{11}$ Because we rely on affiliate financial statement information, we are unable to measure the impact of these topside adjustments. However, topside adjustments bias against our tests detecting income shifting behavior.
} 
to selectively consolidate only certain affiliates, few multinational companies take advantage of them. ${ }^{12}$ This suggests that use of current cross border consolidation policies is very costly.

Third, the multinational firm can undertake real activities at the affiliate to minimize the loss. ${ }^{13}$ For example, the multinational could move research and development activities to a more profitable affiliate or, as a more extreme example, move a physical factory from one jurisdiction to another. This option likely entails significant adjustment costs and will result in a less taxefficient structure in the future, assuming the affiliate returns to profitability.

Finally, the multinational can adjust transfer prices to minimize the reported loss. Because transfer prices have some inherent flexibility, a multinational could potentially reduce taxes using a traditional strategy when all affiliates are profitable, but alter this strategy - to a shift-to-loss strategy — when losses occur in some affiliates. While this option is more costly than the first option (i.e., no response), adjusting transfer prices also generates new tax savings, except in the case that the losses are carried back. This is the behavior we aim to study.

The inherent flexibility in transfer prices arises because market prices for intercompany transactions can be difficult to observe. Firms generally construct a range of prices based on inexact "comparables," or companies with a similar business profile. Most countries will not challenge any well-supported price within the range generated using such methods, and as such, firms often choose the most tax-favored endpoint of the range.

For example, firms with a high-tax affiliate that is purchasing services from a low-tax affiliate will choose a price at the high end of the range to minimize profits in the relatively hightax jurisdiction and maximize profits in the relatively low-tax jurisdiction. If the high-tax affiliate

\footnotetext{
${ }^{12}$ For example, through 2005, only 13 French companies had opted for cross border consolidation (Dorsey \& Whitney LLP, 2006).

${ }^{13}$ We assume that the aggregate level of the multinational's activities was optimal but that its allocation of these activities to affiliates was not. Thus, in our setting, activities are moved rather than increased or decreased.
} 
instead earns a loss, it has several options. First, and least costly, the firm can keep the previous price. Second, the firm can choose a transfer price at the other end of the range to minimize the reported loss. Third, the firm can search for additional or a new set of independent comparable transactions in order to expand the range to include a more favorable endpoint. This change will require some new documentation to support the new range. Finally, if necessary, the firm can identify risks that resulted in the loss (e.g., foreign currency exchange or product failure risk), or other previously uncompensated transactions that the affiliate is party to, and compensate the loss affiliate for that previously un-priced contribution. However, this last option potentially sets a precedent for less tax-favored outcomes in profitable years. Which response the firm will choose will depend on the tax savings and the costs associated with each alternative.

\section{Related Literature}

The literature abounds with evidence that firms reduce income taxes by shifting taxable income from relatively higher-tax jurisdictions to lower-tax jurisdictions. Grubert and Mutti (1991) exploit the relation between profitability and the tax rate as a measure of income shifting and variants of their research design are often used in the literature. Klassen, Lang, and Wolfson (1993) use a similar methodology to study changes in income shifting behavior in response to tax rate changes, while Hines and Rice (1994) employ the research design to study the use of tax havens. The approach of Hines and Rice has become common as a general model of multinational income shifting (Dharmapala, 2014).

Alternative methods for studying tax-motivated income shifting behavior have also been developed. Jacob (1996) considers the volume of intrafirm trade as a measure of income shifting flexibility and shows that tax savings are related to the volume of intrafirm trade. Clausing (2006) finds that the price of intrafirm transactions and trading partners' tax rates are strongly related in a manner consistent with tax-motivated transfer pricing. Overesch (2006) uses 
intercompany accounts receivable $(\mathrm{A} / \mathrm{R})$ to indirectly measure intrafirm prices and shows that the intercompany $\mathrm{A} / \mathrm{R}$ of foreign-owned German subsidiaries with a loss carryforward is less sensitive to the tax rate differential (between the foreign parent and German subsidiary) than is the intercompany $\mathrm{A} / \mathrm{R}$ of foreign-owned German subsidiaries without a loss carryforward. Bernard, Jensen, and Schott (2008) find that the prices that U.S. exporters charge arm's-length customers are significantly higher than the prices that they charge related-parties, and that this price wedge is greater for exports to countries with lower tax rates or with higher import tariffs.

While there is ample evidence of tax-motivated income shifting by multinational firms, the literature has largely focused on the benefit of shifting income from higher-tax affiliates to lower-tax affiliates and ignored the benefit of shifting income from a profitable affiliate to a loss affiliate. ${ }^{14}$ Because the presence of a loss affiliate can alter the income shifting incentives of relatively low-tax profitable affiliates, this omission may have a profound effect on measurement of income shifting. Although Klassen et al. (1993) discuss the difficulty in measuring the tax incentives of unprofitable firms and the potential confounding effect losses have on taxmotivated income shifting behavior, to our knowledge, only Gramlich et al. (2004) and Onji and Vera (2010) attempt to test the effect of loss affiliates on reported profits. ${ }^{15}$

Both Gramlich et al. (2004) and Onji and Vera (2010) find that members of Japanese keiretsu groups (member firms) appear to alter their transfer pricing behaviors in the presence of loss members. Although these results support loss-related income shifting, their data sets do not

\footnotetext{
${ }^{14}$ Much of the tax-motivated income shifting research excludes unprofitable foreign affiliates or unprofitable foreign groups from analysis. However, excluding unprofitable affiliates does not avoid the influence of losses because the effect of loss affiliates should be reflected in the profitability of profitable affiliates, which often remain in the sample. Additionally, research that is only able to measure aggregated foreign versus domestic income, rather than that of specific affiliates, treats the income-shifting incentives of loss affiliates the same as those of profitable affiliates.

${ }^{15}$ Overesch (2006 and 2009) tangentially discusses the potential effects of losses on tax-motivated income shifting but does not explicitly investigate the impact of losses on inferences. While the literature on risk-sharing (for example, Chang and Hong, 2000; Khanna and Yafeh, 2005; and Kim and Yi, 2006) inherently studies the effects of loss affiliates on affiliated groups, it primarily does so from a non-tax angle.
} 
allow the variation in tax rates necessary to directly study the relation between tax rates and profitability. Further, the costs and benefits of shifting income between keiretsu members will differ from those associated with foreign affiliates in a commonly-controlled group.

In a concurrent study that complements ours, Hopland et al. (2014) examine the levels of intercompany payments between affiliated firms in Norway in the presence of affiliates with a loss, finding that some transfer prices are flexible enough to mitigate affiliate losses. Specifically, they document that loss affiliates exhibit lower net outgoing transfer payments relative to profitable affiliates, and that this reduction appears to stem from intercompany transfers for intangibles (rather than tangible goods or debt) via topside, tax-only adjustments. ${ }^{16}$ Our study increases the external validity of their findings by extending the analysis to a multinational setting, allowing an identification strategy that exploits differences in tax incentives across multinational groups and jurisdictions. Our study further differs by estimating tax-motivated income shifting from reported book profits, which are more widely available. We provide evidence that the reported book profits of multinational firms also respond to affiliated losses, suggesting that multinational groups respond quickly to affiliate losses and book shift-toloss transfer prices throughout the year rather than relying only on topside, tax-only adjustments.

While the tax-motivated income shifting literature has largely ignored the impact of losses on cross-jurisdictional income shifting, the effect of losses on other types of tax efficient behavior has been studied. For example, Mackie-Mason (1990) finds that firms with loss carryforwards are significantly less likely to issue debt than firms without loss carryforwards. More recently, Edgerton (2010) shows that firms with loss carryforwards elect bonus depreciation less frequently than fully taxable firms. In addition, De Simone, Robinson, and

\footnotetext{
${ }^{16}$ These types of adjustments are made to tax accounts only and are made after the financial books are closed but before the tax return is filed. We are unable to observe these tax-only adjustments.
} 
Stomberg (2014) provide evidence that firms are less likely to be tax aggressive if they have significant loss carryforwards. These papers estimate that losses significantly affect the taxrelated decisions studied, suggesting that their effect on transfer pricing is worth studying.

We connect these two lines of literature by more directly studying the impact of losses on cross-jurisdictional tax-motivated income shifting behavior. To do so, we develop a method to estimate the expected income of loss affiliates. We then examine the relation between unexplained profits and the benefits of employing a shift-to-loss strategy. Our work differs from the above studies because we posit that losses alter the tax planning strategy rather than simply lessening the tax planning incentives. In that sense, our approach is more like Erickson, Heitzman, and Zhang (2012) and Maydew (1997) who find evidence of tax-motivated intertemporal loss shifting.

\section{DIFFERENCE IN INCOME SHIFTING WITH A LOSS AFFILIATE}

\section{Model and Hypothesis}

In a multinational group consisting exclusively of profitable affiliates, the traditional strategy of shifting income from high-tax affiliates to low-tax affiliates reduces worldwide taxes. This paper suggests that the presence of loss affiliates temporarily confounds these traditional income shifting incentives both by providing high-tax profitable affiliates additional, potentially tax-minimizing recipients of shifted income and by altering the incentives of lower-tax affiliates. Essentially, loss affiliates face a reduced marginal tax rate, potentially zero. Low-tax affiliates continue to have an incentive to receive shifted income but now also have affiliates potentially facing a zero-tax rate to whom they can shift income.

Hines and Rice (1994) develop a model in which each affiliate in a corporate group reports a pre-tax profit, $\pi_{i}$, that is the sum of the pre-tax profit from the economic activity in the 
affiliate, $\rho_{i}$, the amount of profit shifted into or out of the affiliate, $\psi_{i}$, and the cost of any shifting, $a / 2 \times \psi_{i}^{2} / \rho_{i} . \psi_{i}$ would be positive for relatively low-tax affiliates and negative for relatively high-tax affiliates. ${ }^{17}$ Algebraically, this is represented as follows:

$$
\pi_{i}=\rho_{i}+\psi_{i}-\frac{a}{2} \frac{\psi_{i}^{2}}{\rho_{i}}
$$

The Hines and Rice (1994) approach is in the spirit of the "all parties, all taxes, all costs" framework of Scholes, Wilson and Wolfson (1992) in that it attempts to separately identify the benefits and costs associated with shifting income to an affiliate. In equilibrium, the firm maximizes overall profit, which equals the sum of after-local-tax profits of all its affiliates. Hines and Rice (1994) assume profits will not face repatriation taxes and that total profits shifted among affiliates is constrained to be less than or equal to zero.

Because Hines and Rice (1994) estimate their model at the jurisdiction level, aggregating the affiliates of all U.S. companies in the jurisdiction, they do not estimate the income shifted by a particular affiliate. Huizinga and Laeven (2008), however, use this same model to estimate the equilibrium shifting at the affiliate level. Huizinga and Laeven (2008) show that the equilibrium profits shifted to or from affiliate $i, \psi_{i}$, and the composite shifting incentive, $C_{i}$, are:

$$
\begin{aligned}
& \psi_{i}=\frac{-\rho_{i}}{a} C_{i} \\
& \text { where } C_{i}=\frac{\sum_{n \neq i}^{N} \frac{\rho_{n}}{\left(1-\tau_{n}\right)}\left(\tau_{i}-\tau_{n}\right)}{\left(1-\tau_{i}\right) \sum_{n=1}^{N} \frac{\rho_{n}}{\left(1-\tau_{n}\right)}}
\end{aligned}
$$

\footnotetext{
${ }^{17}$ Empirically, we can only infer the affiliate's net value of $\psi_{i}$. That is, an affiliate could both receive shifted profit from a higher-tax affiliate and provide shifted profit to a lower-tax affiliate but we will only estimate net unexpected profit.
} 
$\tau_{i}$ is the statutory tax rate of affiliate $i$ in its jurisdiction. The fraction of the affiliate's income that is shifted is based on the cost parameter, $a$, the affiliate's statutory tax rate, $\tau$, and the weighted average of the difference in the affiliate's tax rate relative to each of the other affiliates' tax rates. Huizinga and Laeven (2008) note that $C$ represents the tax incentive for a particular affiliate relative to others in its affiliated group in the same year. Higher values of $C$ indicate a high-tax affiliate within its group, resulting in a tax incentive to shift profits to affiliates in the group with lower values of $C$.

The Huizinga and Laeven (2008) model does not distinguish between profitable and loss affiliates, that is whether $\rho_{i}$ is positive or negative. However, since the tax rate is typically the statutory tax rate and a negative value of $\rho_{i}$ would yield a negative weight, empirical estimates based on this model employ only profitable firm-jurisdictions or profitable affiliates (e.g., Huizinga and Laeven 2008, De Simone 2016, Markle 2015). To analyze the equilibrium income shifting if affiliate $j$ has losses, we examine the effect of a discrete decrease in the tax rate for affiliate $j ;{ }^{18}$ that is, we assume losses will lower the net present value of taxes paid by the affiliate. To address the challenges that the above model faces in the presence of a loss affiliate, we make two changes to the cost of shifting. First, we replace pre-tax profit, $\rho_{i}$, as the driver of the cost of income shifting with $K_{i}$, where $K_{i}$ represents economic activities such as capital or labor. This is done to avoid negative weights for loss affiliates and is consistent with recent proposals from the OECD that suggest that the level of economic activity in a jurisdiction determines how much profit is reasonable in that jurisdiction (OECD, 2013). Second, we model the cost of shifting as not tax deductible, consistent with an alternative specification considered

\footnotetext{
${ }^{18}$ Throughout the remainder of this section, we denote the loss affiliate as affiliate $j$.
} 
by Huizinga and Laeven (2008). ${ }^{19}$ Whether income-shifting costs are tax deductible is not a primary focus of this paper and this alteration simplifies the model with no effect to inferences. With these two alterations, the equilibrium shifting for affiliate $i$ becomes the following:

$$
\begin{aligned}
& \psi_{i}=\frac{-K_{i}}{a} C_{i} \\
& \text { where } C_{i}=\frac{\sum_{n \neq i} K_{n}\left(\tau_{i}-\tau_{n}\right)}{\sum_{n} K_{n}}
\end{aligned}
$$

The partial derivative of the affiliate's equilibrium shifted income, with respect to its tax incentive $C_{i}$ is $-K_{i} / a$, and with respect to its tax rate, yields the following:

$$
\frac{\partial \psi_{i}}{\partial \tau_{i}}=\frac{K_{i}}{a} \times\left(\frac{K_{i}}{\sum_{n} K_{n}}-1\right)
$$

These derivatives are consistent with the standard negative relation between tax incentives and the profit reported in an affiliate, or more generally, in a jurisdiction. ${ }^{20}$

If affiliate $j$ suffers a loss, we assume that the loss affects the expected present value of the tax rate for this affiliate, which we denote $\theta \tau_{j}$, where $0 \leq \theta \leq 1 .^{21}$ We assume that the affiliate's capital, and therefore its cost of shifting, are unaffected by the loss. The resulting

\footnotetext{
${ }^{19}$ In their empirical estimates, Huizinga and Laeven (2008) use sales to proxy for $\rho$. With regard to deductibility, in footnote 5, the authors state that the specification in which costs are not tax deductible, as in equation (3) here, obtains quantitatively similar results to their main specification. Non-deductible costs of income shifting include centrally borne compliance costs (not charged out to the affiliate) as well as potential penalties. In robustness tests, we confirm that our results are robust to their calculation of $C$ that assumes the costs of shifting are tax deductible.

${ }^{20}$ We assume the effect of the loss is to alter the present value of the statutory tax rate, rather than to alter the present value of the tax incentive variable $C$. Similar results are derived if the loss alters the affiliates value of $C$.

${ }^{21}$ A tax rate for loss affiliates of zero is consistent with either affiliates in jurisdictions that do not allow consolidation, loss carryback or loss carryforward, or with affiliates that do not have fact patterns that will provide a benefit when these provisions are allowed (i.e., no profitable affiliate with the same direct parent in the jurisdiction, losses during the carryback period and expected losses during the carryforward period).
} 
equilibrium shifting at the unprofitable affiliate $j$ that results from the loss, relative to the equilibrium shifting had the affiliate been profitable, is as follows:

$$
\psi_{j}^{L}-\psi_{j}^{P}=\frac{K_{j}}{a}(1-\theta) C_{j}
$$

where the shifting superscripts denote a loss, $L$, or profit, $P$. If this difference is positive, additional amounts are shifted to a loss affiliate, and thus the reported profits in a loss affiliate will be higher. The effect of the loss on the equilibrium relation between the affiliate's tax incentives and its shifted income is as follows:

$$
\frac{\partial\left(\psi_{j}^{L}-\psi_{j}^{P}\right)}{\partial C_{j}}=\frac{\partial\left(\psi_{j}^{L}-\psi_{j}^{P}\right)}{\partial \tau_{j}}=\frac{K_{j}}{a}(1-\theta)
$$

Thus, the difference in shifting behavior relative to the same affiliate if it reported profits is positively related to the tax incentive, and the degree to which it is positive increases as the affiliate's tax rate goes to zero (i.e., as $\theta$ approaches 0 ). It is also worth noting that if $\theta=0$, the derivative of the amount shifting for the loss affiliate with respect to the tax rate (i.e., equation (6) plus equation (4)), is positive.

The Appendix provides a numerical example of the effect of loss affiliates on income shifting. Given an assumed cost structure of income shifting (costs are quadratic, $a=10$ ), this example demonstrates that when all affiliates are profitable, income is shifted into affiliates with low tax incentives. Specifically, in Case 1 of the Appendix, affiliate $j$ receives 0.52 in income from the affiliates with high tax incentives, including affiliate $k$ who shifts out 0.38 of income. In Case 2 of the Appendix, affiliates $j$ and $k$ experience losses and now both receive income, of 0.83 and 0.53 respectively. Thus, the income-shifting pattern changes in equilibrium. Further, the effect of the difference in tax incentives between affiliates becomes much less significant in the presence of losses (difference in $\psi$ between affiliates $j$ and $k$ of 0.9 in Case 1 vs. 0.3 in Case 2) 
because high tax-incentive affiliates alter their income shifting to a much greater extent than low tax-incentive affiliates when the affiliates experience losses. That is, comparing Case 1 income shifting to Case 2 income shifting, the high tax-incentive affiliate changes from a provider of income to a recipient of income whereas the low tax-incentive affiliate alters its income shifting to a much smaller extent. The existence of the loss alters the traditional relation between unexpected profit and the tax incentive, which is the basis for our first hypothesis:

H1: The relation between unexplained profit and the tax incentives is less negative for loss affiliates than for profitable affiliates.

The above analysis does not consider the costs the company will bear to alter its income distribution strategy. Thus, our second hypothesis considers the cost-benefit trade-off a firm analyzes before deviating from a traditional income shifting strategy to adopt a shift-to-loss strategy. If the costs of altering the income shifting strategies are large enough, the costs will exceed the benefits for some affiliates. It will be most likely that benefits exceed costs for affiliates with high benefits.

Holding $\theta$ constant, the worldwide tax savings due to adopting a shift-to-loss strategy are larger when the loss occurs in a higher tax rate loss affiliates than when the loss occurs in a lower tax rate loss affiliates. Said another way, the decrease in tax benefit due to $\theta$ (and thus the change in tax incentives due to $\theta$ ) is increasing in the tax rate. The benefits of a shift-to-loss strategy in response to a high-tax loss affiliate will therefore be relatively larger, making it more likely, on average, that the benefits will exceed the costs.

The Appendix provides a numerical example of this effect. Comparing income shifting, $\psi$, in Case 1 to Case 2, the high tax-incentive affiliate changes from a provider of income $(\psi<0)$ to a recipient of income $(\psi>0)$, whereas the low tax-incentive affiliate alters its income shifting to a much smaller extent ( $\psi>0$ in both cases). The last line of the example calculates the 
difference in after-tax profit given a loss but using the traditional profit-shifting strategy in Case 1 and the new optimal shift-to-loss strategy in Case 2, ignoring costs to change the shifting strategy. This line shows that the benefit obtained by shifting into the high tax-rate loss affiliate, $k$, is much larger than that obtained by shifting into the low tax-rate loss affiliate, $j$. Thus, on average, we would expect a stronger reaction to losses by affiliates in high tax-rate jurisdictions:

H2: The relation between unexplained profit and the tax incentives is less negative for relatively higher tax rate loss affiliates than for relatively lower tax rate loss affiliates.

\section{Research Design and Variable Definitions}

To estimate their models, Hines and Rice (1994) and Huizinga and Laeven (2008) apply the Cobb-Douglas production function to estimate the profits associated with the economic activity in the jurisdiction.

$$
\rho \approx Q-w L=\left(1-\beta_{3}\right) c K^{\beta_{2}} L^{\beta_{3}} A^{\beta_{4}} e^{u}
$$

where $\rho$ is the profit before shifting as in equation (1). Applying log transformations to both sides of equation (6) and incorporating equilibrium income shifting, as specified in the model above, yields the following estimation equation:

$$
\log \pi_{i}=\beta_{1}+\beta_{2} \log K_{i}+\beta_{3} \log L_{i}+\beta_{4} \log A_{i}+\beta_{5} T I_{i}+u_{i}
$$

where $K_{i}$ is affiliate capital, $L_{i}$ is affiliate labor, $A_{i}$ is a measure of productivity, and $T I_{i}$ is a measure of tax incentive for the affiliate, (e.g., the jurisdiction's tax rate or $C$ in Huizinga and Laeven, 2008). $\beta_{5}$ is an empirical estimate of the average responsiveness to income-shifting incentives. ${ }^{22}$

\footnotetext{
${ }^{22}$ Variation in explained profit associated with the tax rate of the foreign affiliate is attributed to either income shifting or implicit taxes. A negative coefficient on $\tau_{i}$ suggests that higher rates leads to lower profitability. This result is attributed to income shifting-firms report less taxable profit in higher tax jurisdictions and more taxable profit in lower tax jurisdictions to minimize income taxes. A positive coefficient on $\tau_{i}$ suggests that higher rates lead to higher profitability and is attributed to implicit taxes; under perfect competition, total costs should equalize so that jurisdictions with higher (lower) tax will have lower (higher) non-tax costs resulting in higher (lower) $\pi_{i}$.
} 
The model above is commonly used in the income shifting literature. However, it is not conducive to a study of loss affiliates because of its log specification. Claessens and Laeven (2004) avoid this limitation by specifying $\pi_{i}$ as return on assets (ROA) plus one. We employ this approach, scaling the production function in equation (7) by assets and adding one to the dependent variable before taking logs. ${ }^{23}$ This specification allows us to estimate our regressions on a sample that includes both profitable and unprofitable affiliates.

We add to the model variables intended to capture economic factors that induce losses because the Cobb-Douglas production function assumes all factors of production and their effects on output are positive. We include a proxy for the age of the firm because the lifecycle of the firm affects the probability of loss. Significant changes in the local economy or industry ("shocks") will affect reported profit, and thus we incorporate both a jurisdiction-year shock variable and country-industry-year shock variable. Finally, we add a binary variable to denote an unprofitable observation. Because the model below does not allow the tax rate to vary with profitability, it essentially estimates profit (or loss) given traditional income shifting incentives.

$$
\begin{aligned}
\ln \left(\pi_{i}+1\right)= & \beta_{0}+\beta_{1} * \ln \left(\text { TangibleAssets }_{i t}\right)+\beta_{2} * \ln \left(\text { CompExp }_{i t}\right)+\beta_{3} * \text { IndustryROA }_{t}+ \\
& \beta_{4}{ }^{*} \text { Age }_{i t}+\beta_{5} * \Delta \text { GDP }_{t}+\beta_{6} * \Delta \text { MarketSize }_{t}+\beta_{7} * \text { TaxIncentive }_{i t}+\beta_{8}{ }^{*} \text { Loss }_{i t}
\end{aligned}
$$

We estimate this model on a sample of European affiliates. All variables are from the Amadeus database unless otherwise noted. Profit, $\pi_{i}$, is ROA, computed as EBIT divided by total assets (TOAS). Following Huizinga and Laeven (2008), we proxy for capital using tangible fixed assets reported on the balance sheet (TFAS) and for labor using compensation expense reported on the income statement $(S T A F)$. Productivity is specified as IndustryROA, which is defined as the median ROA by two-digit NACE industry-country-year, calculated using all affiliated and independent firms. Age is year $t$ less the first year the affiliate appears in the Amadeus database.

\footnotetext{
${ }^{23}$ Scaling $\rho_{i}$ in equation (7) by assets results in ROA on the left-hand-side of the equation. Scaling the right-handside of equation (7) by assets changes the exponent on $K_{i}$ from $\beta_{2}$ to $\left(\beta_{2}-1\right)$.
} 
The Shock variables we include are $\Delta G D P$ and $\Delta M k t$ Size. ${ }^{24} \Delta G D P$ is the percent change in country-year GDP per capita; GDP is as reported by the European Commission. $\Delta M k t$ Size is the country-industry-year sum of all affiliate and standalone sales in year $t$ less the sum in year $t-1$, scaled by $1,000,000$.

We alternatively measure TaxIncentive using an adaptation of $C$, the measure developed by Huizinga and Laeven (2008) to take into account the entire portfolio of tax rates faced by a firm, or the country-year statutory tax rate of the affiliate, STR. In our study, $C$ represents a capital-weighted differential tax rate of the affiliate relative to all related firms in the same multinational group-year, as reflected in equation (3). To avoid multicollinearity when interactions are introduced, the affiliate-level tax rate variable STR is mean centered (Guenther and Sansing, 2010; Aiken and West, 1991) ${ }^{25}$ Loss equals one if EBIT is less than zero. The model described above, from which we derive our hypotheses, suggests that Loss should equal 1 if $\rho$, the profits before shifting, are negative. In the main tests, we use the sign of EBIT as our empirical proxy for the sign of $\rho$; however, in specification checking procedures, we assess the sensitivity of our results to the proxy. All measures are calculated at the affiliate-year, firm-year, or country-industry-year level using Bureau van Dijk’s Amadeus database.

To test hypothesis H1, we interact Loss with TaxIncentive, as below:

$$
\begin{aligned}
\ln \left(\pi_{i}+1\right)= & \beta_{0}+\beta_{1} * \ln \left(\text { TangibleAssets }_{i t}\right)+\beta_{2} * \ln \left(\text { CompExp }_{i t}\right)+\beta_{3} * \text { IndustryROA }_{t}+ \\
& \beta_{4}{ }^{*} \text { Age }_{i t}+\beta_{5}{ }^{*} \Delta \text { GDP }_{t}+\beta_{6} * \Delta \text { MarketSize }_{t}+\beta_{7} * \text { TaxIncentive }_{i t}+\beta_{8}{ }^{*} \text { Loss }_{i t}+ \\
& \beta_{9}{ }^{*} \text { Loss }_{i t}{ }^{*} \text { TaxIncentive }_{i t}
\end{aligned}
$$

H1 predicts a positive coefficient for $\beta$, consistent with equation (6).

\footnotetext{
${ }^{24}$ We use median industry-country-year ROA as the measure of productivity instead of GDP because we include change in GDP as a proxy for economic shock. In untabulated tests, we also include the change in market share of the affiliate; however the coefficient on this variable is not statistically significant at conventional levels and so we exclude it from main tests.

${ }^{25}$ By construction, $C$ is effectively mean-centered within firm.
} 
To test hypothesis $\mathrm{H} 2$, we add an indicator variable for whether the affiliate-year is in the top quartile of STR for that year: ${ }^{26}$

$$
\begin{aligned}
& \ln \left(\pi_{i}+1\right)=\beta_{0}+\beta_{1} * \ln \left(\text { TangibleAssets }_{i t}\right)+\beta_{2} * \ln \left(\text { CompExp }_{i t}\right)+\beta_{3} * \text { IndustryROA }_{t}+ \\
& \beta_{4} * \text { Age }_{i t}+\beta_{5} * \Delta G D P_{t}+\beta_{6} * \Delta \text { MarketSize }_{t}+\beta_{7} * \text { TaxIncentive }_{i t}+\beta_{8} * \text { Loss }_{i t}+ \\
& \beta_{9} * \text { Loss }_{i t} * \text {TTaxIncentive }_{i t}+\beta_{10} * \text {HighSTR}_{i t}+\beta_{11} * \text { HighSTR }_{i t} * \text { Loss }_{i t}+ \\
& \beta_{12}{ }^{*} \text {HighSTR }_{i t} * \text { TaxIncentive }_{i t}+\beta_{13} * \operatorname{HighSTR}_{i t} * \operatorname{Loss}_{i t} * \text { Tax Incentive }_{i t}
\end{aligned}
$$

We continue to predict a positive coefficient $\beta_{9}$ following $\mathrm{H} 1$ and further predict a positive coefficient $\beta_{13}$ following $\mathrm{H} 2$. It is important to note that we use the statutory tax rate for our exploration of $\mathrm{H} 2$. In doing so, we draw a distinction between the tax incentive at the affiliate level, which considers the position of the particular affiliate within the corporate group, and the jurisdiction's tax rate that would apply broadly to all entities within that jurisdiction.

\section{Sample}

The Amadeus database contains financial and operating information on independent and affiliated European firms. We use unconsolidated company information from Amadeus over the period 2003 to 2012 for all tests. Our sample selection is detailed in Table 1.

\section{(insert Table 1 around here)}

Table 1 outlines that we limit our sample to controlled groups with at least one foreign affiliate with greater than 50 percent total (direct and indirect) ownership. ${ }^{27}$ We require that both the parent and this foreign affiliate be located in Europe, where Amadeus includes more detailed information, and that the affiliate not be missing earnings before interest and taxes (Amadeus variable $E B I T)$. These criteria yield a beginning sample of 222,461 affiliate-year observations.

To remain in the sample, we require an industry classification (NACE) code because we expect that profitability varies by industry and so include an industry-level shock measure. We

\footnotetext{
${ }^{26}$ In untabulated tests, we confirm results are robust to alternatively defining HighSTR as the top 20 percent and top 33 percent of the sample when using $C$ or STR as the proxy for TaxIncentive.

${ }^{27}$ Ninety-nine percent of the affiliates in our sample are owned at least ninety percent.
} 
exclude affiliated groups in banking and insurance industries because their profitability is less easily estimated using assets and compensation. We further require that the consolidated group be profitable, reporting a return on sales $\left(\sum P L B T / \Sigma R E V\right)$ of at least three percent, because consolidated losses create incentives to change the income shifting strategy that are unrelated to our research question (Stock, 2013) ${ }^{28}$ For the purposes of estimation, we require tangible fixed assets (TFAS) and total assets (TOAS), and compensation expense (STAF) to be positive and we require Age and both measures of shock ( $\triangle G D P$ and $\Delta M k t$ Size) for each affiliate. Affiliate-level data requirements and differences in reporting requirements across countries and entity types inevitably result in the inability to include in estimation all affiliates within a multinational group-year. Finally, we require $R O A$ to be greater than or equal to -1.0. Our final sample consists of 59,743 affiliate-years representing 2,662 unique controlled groups, of which Loss $=1$ for 11,838 affiliate-years and the remaining 47,905 affiliate-years are identified as profitable.

\section{Summary Statistics}

Table 2 presents summary statistics by country. The number of affiliate-years by country varies from 154 in Ireland to 8,376 in Italy. We also provide averages over the sample period 2003-2012 of key inputs to our country-year proxies. Average statutory tax rates vary by country from a low of 10 percent in Bosnia and Herzegovina and in Serbia to a high of 34 percent in Belgium, Germany and Italy. Most countries do not allow a carryback and the maximum carryback period is three years (France). All sample countries except Estonia allow a carryforward of at least five years.

(insert Table 2 around here)

\footnotetext{
${ }^{28} \mathrm{We}$ calculate consolidated return on sales for the affiliates in our sample, rather than use the consolidated figures available in Amadeus, to ensure that we appropriately measure the incentives and ability of the affiliates in our sample to achieve a shift-to-loss strategy. This approach also acknowledges that we do not have data for all affiliates in the corporate groups. However, results are robust to alternatively using consolidated figures to calculate the return on sales sample criterion.
} 
Table 3 presents summary statistics for sample affiliate-years. Measures from affiliate unconsolidated financial statements are winsorized at 1/99 percent. As expected given our sample selection, sample affiliates report a positive $R O A$ on average. Approximately 20 percent of the observations report a negative $\operatorname{EBIT}(\operatorname{Los}=1)$. The average affiliate in our sample faces a statutory tax rate of 28.6 percent.

\section{(insert Table 3 around here)}

Panels $\mathrm{B}$ and $\mathrm{C}$ present descriptive statistics for affiliates experiencing a loss and reporting profit, respectively. Comparing the panels in Table 3, the average loss affiliate is smaller than the average profitable affiliate based on TangibleAssets, CompExp and Sales but has a similar amount of Assets.

Table 4 presents correlations between our income prediction variables. The correlation between $\ln$ (TangibleAssets) and $\ln ($ CompExp) is positive and statistically significant at 0.59 ; though concerning, this is in line with prior literature. ${ }^{29}$

$$
\text { (insert Table } 4 \text { around here) }
$$

\section{RESULTS}

\section{Results of tests of hypothesis H1}

To provide baseline information, we first estimate precursors to the profit prediction model specified in equation (9). Table 5, Panel A presents these regressions. On a sample of profitable affiliates, the Cobb-Douglas specification in column (1), using earnings before interest and taxes $(E B I T)$ as the measure of output, estimates coefficients consistent with prior research. Specifically, $\ln$ (TangibleAssets), $\ln ($ CompExp $)$ and IndustryROA are positively related to profitability as expected and the model achieves an $\mathrm{R}^{2}$ of over 60 percent. When we measure

\footnotetext{
${ }^{29}$ For example, Huizinga and Laeven (2008) report a correlation of 0.84 between Capital and Labor.
} 
output as $R O A$, we expect a negative coefficient on capital because we deflate both sides by TangibleAssets before taking logs, and the Cobb-Douglas exponent on capital is generally assumed to be less than one. Consistent with this expectation, we report a negative coefficient on $\ln ($ TangibleAssets $)$ in column (2). $\operatorname{Ln}($ CompExp) and IndustryROA remain positively related to profitability. Though all of the coefficients other than $\ln$ (TangibleAssets) remain identical between columns (1) and (2), the $\mathrm{R}^{2}$ in column (2) falls dramatically to only 13 percent because the ratio $R O A$ has significantly more variance relative to size than does the level EBIT.

(insert Table 5 around here)

Finally, columns (3) and (4) introduce $(R O A+1)$ as the measure of profitability. A comparison of columns (2) and (3) demonstrates that the addition of one to the $R O A$ decreases the magnitude of the coefficients, but does not change the sign or significance of them. The purpose of adding one to $R O A$ is to be able to include loss affiliates in the sample, and their inclusion, in column (4), does significantly change regression estimates. In particular, the importance of both $\ln ($ TangibleAssets $)$ and $C$ is reduced whereas IndustryROA becomes more important to the model.

We test our first hypothesis in Panel B of Table 5. To the model estimated in column (4) of Table 5, Panel A, we add additional economic shock and intercept variables to improve the model's performance for loss affiliates in our hypothesis tests. Specifically, column (1) includes $\ln ($ Age $)$ and the Shock variables and column (2) includes $\ln ($ Age $)$, the Shock variables and the Loss indicator, as specified in equation (9). Both these models implicitly estimate expected reported profit given economic shocks and traditional income tax shifting incentives. As expected, we estimate a negative coefficient on the Loss indicator. By including this indicator, the other variables better predict profitability. Specifically, the coefficient on IndustryROA returns to a level similar to that estimated on the all profitable sample in column (3) of Panel A. 
Though the inclusion of the Shock variables does not dramatically improve the fit of the model, the inclusion of the Loss intercept variable does, increasing the model's fit from an $\mathrm{R}^{2}$ of 9.6 percent to 30.6 percent.

In column (3), we estimate the full model outlined in equation (10), which interacts the tax incentive variable with Loss to test hypothesis H1. Though the main effect of $C$ has a coefficient that is significantly negative and consistent with Column (3) of Panel A, the interaction of $C$ with the Loss indicator is positive and statistically significant at the $1 \%$ level of statistical significance, consistent with our first hypothesis. These results suggest that while profitable affiliates decrease profits reported in higher tax-rate jurisdictions, firms respond to the incentives induced by loss affiliates to reduce the shifting of profits out of these higher tax rate jurisdictions, and in fact report higher unexpected profits in such jurisdictions.

For profitable affiliates, we estimate a coefficient with respect to the composite tax incentive of -0.088 that translates to a semi-elasticity of -0.75 at the mean ROA, consistent with the past literature (Dharmapala, 2014). However, the sum of coefficients with respect to the composite tax rate of loss affiliates is +0.162 , translating to a semi-elasticity of +1.24 at the mean ROA. $^{30}$ Our point estimate for profitable affiliates implies that an increase of one standard deviation (0.047) in the tax rate incentives and mean return on assets of 13.3 is associated with a return on assets of $12.8,0.5$ percentage points lower. Our point estimate for unprofitable affiliates implies that an increase of one standard deviation in the tax rate incentives of an unprofitable affiliate with average return on assets of -11.6 is associated with a higher return on assets of -10.9 , or 0.7 percentage points higher.

\footnotetext{
${ }^{30}$ The estimates are calculated as $\exp \left[\right.$ coefficient on $C^{*}$ change in $C+\ln ($ mean $\left.\mathrm{ROA}+1)\right]-1$ and $\exp [$ (coefficient on $C+$ coefficient on $\left.\operatorname{Loss}^{*} C\right) *$ change in $C+\ln ($ mean $\left.\mathrm{ROA}+1)\right]-1$, respectively. For the calculation of semi-elasticity, the change in $C$ is $1 \%$.
} 
Though we provide an estimate above, interpreting differences in $C$ is difficult. Consider the following simple example. For a multinational group with two similarly sized affiliates who are subject to the sample median statutory tax rate of 30 percent, an increase in an affiliate's own tax rate from 30 percent to 40 percent results in an increase in $C$ approximately equal to the sample standard deviation of 0.047 used to calculate the figures above. In this simple example of only two affiliates in the multinational group, the same change in $C$ for the same affiliate could instead be obtained by a decrease in the related affiliate's tax rate from 30 percent to 20 percent. If we expand the group to three similarly-sized affiliates who face the sample median statutory rate, the statutory rate of the affiliate in question must increase to approximately 37.5 percent or the statutory rate of one of its affiliates must decrease to 15 percent to achieve the same standard deviation in $C$. If we remove the assumption that the affiliates are similarly-sized, the same increase in $C$ would require a larger change in a smaller affiliate (smaller change in a larger affiliate) because $C$ is capital-weighted. The complexity in our very simple example demonstrates that the possible avenues for achieving a 0.047 increase in $C$ multiplies as the number of affiliates in the group increases and/or as the size of these affiliates differs.

Due both to the difficulty in interpreting results related to the composite tax variable, $C$, and to potential measurement error in $C$, we also test our hypotheses using the statutory tax rate. ${ }^{31}$ Table 6 presents these results and mirrors Panel B of Table 5 using STR to proxy for TaxIncentive. ${ }^{32}$ Results are again consistent with $\mathrm{H} 1$. We estimate a significantly negative relation between unexpected profit and the statutory tax rate for profitable affiliates but a

\footnotetext{
${ }^{31}$ The composite tax variable requires information on all the affiliates of a multinational group to be complete. It is especially susceptible to mismeasurement when the missing affiliates are near the tails of the tax rate distribution. For example, omitted low-tax affiliates (such as haven affiliates and holding companies that may escape reporting requirements by having few assets or employees) create mismeasurement because affiliates nearer the middle of the group's tax rate distribution (and thus having only a mild tax incentive) appear to be near the bottom of the distribution with a strong incentive to receive shifted income.

${ }^{32}$ In untabulated tests, we estimate Panel A of Table 5 using STR to proxy for TaxIncentive. Results are qualitatively similar.
} 
significantly positive relation between unexpected profit and the statutory tax rate for loss affiliates. Our point estimates imply that a one percent increase in the statutory tax rate for profitable affiliates is associated with a 0.08 percentage point decrease in profitability, but that the same change in statutory rate for loss affiliates is associated with a 0.08 percent increase in profitability on average. ${ }^{33}$ These two sets of tests provide support for our hypothesis that the reported profit of loss affiliates exhibits a different relation with tax incentives than does the reported profit of profitable affiliates.

\section{(insert Table 6 around here)}

The estimates in Panel B of Table 5 and in Table 6 provides insight into differences in unexpected reported profit that results from a large discrete change in tax rates within a single country, or large differences in tax rates across countries (e.g., from entering a tax haven). Because the estimates involve affiliates that, if profitable, would face tax rates equal to the statutory tax rate but now are assumed to face a tax rate that is much lower, the estimates do not represent a marginal effect inherent in extant methods (i.e., those based on Hines and Rice, 1994, and summarized in Dharmapala, 2014). However, because the losses are likely temporary, the shifting response to a loss affiliate is expected to be muted relative to a permanent change in tax rates to zero. The estimates therefore provide a lower bound on the difference in reported income that is introduced by a large difference in tax rates across affiliates and suggest that multinational firms respond to even temporary tax rate changes when those changes are large.

\footnotetext{
${ }^{33}$ The estimate for profitable affiliates is calculated as $\exp [$ coefficient on $S T R * 1 \%+\ln ($ mean $\mathrm{ROA}+1)]-1$, which reflects a decrease from the average ROA of 13.30 to 13.22 . The estimate for loss affiliates is calculated as $\exp [($ coefficient on $S T R+$ coefficient on $\operatorname{LosS} * S T R) * 1 \%+\ln ($ mean ROA +1$)]-1$, which reflects an increase from the average ROA of -11.56 to -11.48 .
} 


\section{Results of tests of hypotheses $\mathrm{H} 2$}

We next test our second hypothesis, that the difference in responsiveness of unexpected profit to tax incentives between profitable and loss affiliates is higher for affiliates located in a higher-tax jurisdiction. This hypothesis considers that high-tax profitable affiliates are providers of shifted income while a high-tax loss affiliate may become a recipient of shifted income, resulting in a larger difference in responsiveness than between low-tax profitable and loss affiliates, which are both expected to be recipients of shifted income, on average. We test $\mathrm{H} 2$ by incorporating an indicator variable, HighSTR, into our tests of H1, as specified in equation (11). $\mathrm{H} 2$ predicts a positive coefficient on the interaction between HighSTR, Loss, and TaxIncentive.

Table 7 presents results of our tests of $\mathrm{H} 2$. We use $C$ as the TaxIncentive proxy in column (1) while STR measures the tax incentive in column (2). We continue to estimate a negative coefficient on TaxIncentive and a positive coefficient on Loss*TaxIncentive in both specifications. These coefficients capture, respectively, the relation for profitable and loss affiliates not in the highest quartile of $S T R$. We estimate insignificant coefficients on $\operatorname{HighSTR}^{*}$ TaxIncentive, which is consistent with the level of the statutory tax rate not affecting the income shifting incentives of profitable affiliates. That is, we fail to show that profitable high-tax affiliates have a responsiveness to income-shifting incentives that is different from the responsiveness of profitable low-tax affiliates.

Consistent with $\mathrm{H} 2$, we estimate significantly positive coefficients on HighSTR* Loss* TaxIncentive. ${ }^{34}$ This result suggests that the difference in the responsiveness of unexpected profit to the tax incentive is largest for affiliates located in relatively high statutory tax rate jurisdictions. Specifically, for the estimates in column (1) using $C$, we estimate that a one

\footnotetext{
${ }^{34}$ In untabulated tests, we replace HighSTR with HighC in tests where we use $C$ as the proxy for TaxIncentive. Coefficients become approximately half as large, suggesting some noise in the measure.
} 
percent increase in the statutory tax rate for the average loss affiliate increases reported profit (decreases reported loss) by 6.66 percent when the affiliate faces high tax rates but increases reported profit (decreases reported loss) by only 0.86 percent when the affiliate faces low tax rates. Thus, though experiencing a loss alters the income shifting for the average loss affiliate and its related profitable affiliates, the difference relative to traditional income shifting incentives is most pronounced for high-tax loss affiliates.

(insert Table 7 around here)

\section{ADDITIONAL ANALYSES AND ROBUSTNESS}

\section{Additional Analyses}

We extend our analysis to consider that income shifting must be multinational groupneutral. That is, if loss affiliates are receiving more shifted income or providing less shifted income, profitable affiliates must balance this difference. We analyze the entire affiliated group and create a binary variable that indicates whether a profitable affiliate has any loss affiliates or is part of an all-profitable group and include this variable in equation (10). If profitable affiliates become less sensitive to typical tax incentives because the traditional strategy is being disrupted, we expect the interaction of this indicator variable with the tax incentive proxies to be positive. If loss affiliates are ignored in the transfer pricing strategy, with profit shifting continuing as normal among the profitable affiliates, we expect this coefficient to be zero. Table 8 presents results of estimating this equation using $C$ and $S T R$ in turn as proxies for the tax incentive.

(insert Table 8 around here)

We continue to estimate a negative relation between unexpected profit and tax incentives for profitable firms in an all-profitable affiliated group and that this relation is significantly less negative (and even significantly positive) for loss affiliates in other affiliated groups. The 
coefficient on ProfitWithLossAff*TaxIncentive is significantly positive, suggesting that profitable affiliates in groups with an associated loss affiliate are less sensitive to the traditional income shifting tax incentives. Overall these results confirm that loss affiliates are considered in the overall transfer pricing strategy of the multinational group and that their existence is disruptive to the traditional pattern of high-tax to low-tax income shifting.

Comparing results in Table 8 to results elsewhere in the paper also provides evidence regarding the degree of understatement in previous research. In Panel A of Table 5, we estimate a coefficient for profitable affiliates of -0.095 . We estimate a similar coefficient in Panel B when we separate the profitable affiliates from loss affiliates. However, in both of these tests, the group of profitable affiliates includes both those in an all-profitable group and those affiliated with a loss affiliate. In Table 8, when we separate these two types of profitable affiliates, we estimate a significantly larger coefficient (-0.176) for those in an all-profitable group. The coefficients in the two tables imply semi-elasticities of -0.81 and -1.50 , respectively. Thus, controlling for the effect of loss affiliates on the incentives of their profitable affiliates almost doubles the semielasticity.

We further examine whether the presence of a loss affiliate in a multinational group-year biases the estimated effect of an affiliate's tax incentives on reported profits. Specifically, we reestimate the first three columns (the EBIT $>0$ specifications) reported in Panels A of Tables 5 and 6 but include a group-year indicator variable equal to 1 if the affiliate has a related unprofitable affiliate. We interact this indicator variable with the tax incentive variable to capture the difference in the responsiveness to income-shifting incentives of profitable affiliates in the presence of loss affiliates relative to an all-profitable group. We only obtain significance on the interaction when using $\log (R O A+1)$ as the dependent variable with the tax incentive variable $C$, suggesting some bias to the estimated effect of the tax incentive variable $C$ in the presence of 
loss affiliates. The lack of significance on the interaction when using the other dependent variables or $S T R$ as the tax incentive variable is perhaps not surprising given that 85 percent of the profitable observations in our sample are affiliated with at least one loss affiliate.

\section{Robustness tests}

To confirm the robustness of our results, we undertake a number of additional tests. First, we confirm that results are robust to an alternative measure of profit that does not include the effect of income shifting through debt. Using pre-tax income (Amadeus variable PLBT) instead of EBIT to calculate dependent variables for profit and to characterize loss affiliates, we reestimate all columns of both panels of Tables 5 and 6 . Results are robust to measuring profitability with pre-tax income. We observe similar signs, magnitudes, and significance on all variables of interest.

Second, we more closely follow prior literature (specifically, Huizinga and Laeven 2008) in two research design choices. First, we use the natural log of GDP per capita as the measure of productivity instead of industry-country-year ROA. We continue to include $\triangle G D P$ despite its higher correlation with $\ln G D P$. Inferences remain unchanged. We observe similar signs, magnitudes, and significance on all variables except the tax incentive variables, the effect of which is larger than reported in Tables 5 and 6 . In the final specification where we test H1, we estimate a coefficient on $C$ of -0.1825 (p-value $<0.01$ ) or on $S T R$ of -0.2298 (p-value $<0.01$ ). Similarly, the estimated coefficient on the interaction between $C(S T R)$ and Loss when using $\ln G D P$ as the measure of productivity is 0.3802 (p-value $<0.01)(0.2909$, p-value $<0.01)$, which is higher than that reported in Table 5 (Table 6). We also confirm that results are robust to assuming the tax deductibility of income shifting costs in calculating $C$. Specifically, in tests of H1 using this alternative calculation of $C$, we find the same signs and significance, and very 
similar magnitudes, on all control variables. We estimate a coefficient on $C$ of -0.0849 (p-value $<$ 0.01 ) and a coefficient of 0.2284 (p-value $<0.01$ ) on the interaction between $C$ and Loss.

Third, instead of calculating an industry-country-year measure of productivity (IndustryROA), we include industry-country-year fixed effects. The use of industry-country-year fixed effects precludes the use of the productivity measure (IndustryROA), the shock variables ( $\triangle G D P$ and $\triangle M k t S i z e$ ), and the country-year tax incentive variable $(S T R)$. We therefore can only estimate and discuss results using the tax incentive variable $C$. Using industry-country-year fixed effects, we obtain similar signs and significance on all variables. We obtain higher magnitudes for the effect of labor on reported profits (e.g., 0.0032 , p-value $<0.01$ in our test of H1) and for the interaction between $C$ and Loss $(0.3878$, p-value $<0.01)$, however all other magnitudes are similar to those reported in Table 5.

Next, we aim to ensure that our results are not affected by our inability to observe data for all affiliates. Thus, we limit our sample to multinationals with only affiliates for which we have data. Imposing this restriction drastically reduces our sample to 9,442 affiliate-years when using the tax incentive variable $C$ and 10,044 affiliate-years when using the tax incentive variable $S T R$. Nonetheless, estimating our tests on this sub-sample generates similar inferences as those reported in Tables 5 and 6 . When testing H1, we estimate a larger magnitude for the effect of the tax incentive variable $C$ on reported profits $(-0.1574$, p-value $<0.01)$ when restricting our sample to fully-observable group-years and on the interaction between $C$ and Loss $(0.4563, \mathrm{p}$-value $=0.04)$, however the economic significance of the interaction is weaker. We observe a similar pattern of results on $S T R(-0.0883, \mathrm{p}$-value $<0.01)$ and the interaction between STR and Loss (0.3758, p-value $=0.02)$.

We next test the sensitivity of our results to our treatment of affiliates with very small profits, which likely includes affiliates that would have been unprofitable absent income shifting. 
In untabulated robustness tests, we omit affiliates with very small profits, defined as affiliateyears reporting ROS below one percent, from the sample and re-estimate equation (10). Results for $\mathrm{H} 1$ are robust to eliminating these observations. This test is not sensitive to alternative small profit thresholds, including ROS of less than 1.5 percent or 0.5 percent. If we instead include an indicator variable for observations with small profits, we continue to find a positive and significant coefficient on the interaction between the loss indicator variable and tax incentives, consistent with results reported in Tables 5 and 6 . Further, we find a negative and significant coefficient on the indicator variable for small profits and a positive and significant coefficient on the interaction between the small profit indicator and tax incentives, consistent with these small profit observations behaving similar to loss affiliates in $\mathrm{H} 1$. The interaction between the small profit indicator and tax incentives results are robust to alternative ROS thresholds except 0.5 percent, where only 1,360 observations meet the small profit definition.

We also group small profit affiliates together with small loss affiliates using the threshold of plus or minus one percent ROS. Dropping all small ROS affiliates from the sample and reestimating equation (10), we continue to find results consistent with $\mathrm{H} 1$ for loss affiliates (now defined as reporting ROS less than -1 percent). Including an indicator for the group of small ROS affiliates and the interaction between this indicator and tax incentives, we continue to find a positive and significant interaction between the loss indicator variable and tax incentives, consistent with $\mathrm{H1}$, as well as a positive and significant interaction between the small ROS indicator variable and tax incentives, suggesting that the group of small ROS affiliates behave like loss affiliates. These results are robust to using 1.5 percent and 0.5 percent bands of ROS as the threshold for defining small profit/loss.

We also consider the sensitivity of the results to our decision to require group ROS to be greater than or equal to three percent. We test three alternative group ROS cut-offs: 2 percent, 1 
percent, and 0 percent. These alternative sample selection criteria do not affect results. In all specifications, we continue to find signs, magnitudes, and significance of all variables consistent with those reported in Tables 5 and 6 . Results are also largely unaffected when using these same cut-offs and reported ROS from the parent company's consolidated financial statements, instead of calculating a group-wide ROS based on affiliate-level financials.

\section{CONCLUSION}

Our paper studies a tax-motivated income shifting strategy that exploits losses earned by unprofitable affiliates of a multinational group. By shifting income from profitable affiliates to loss affiliates, multinational corporations can reduce their worldwide tax burden. However, there are considerable costs associated with this strategy such that its usage should not be assumed. Thus, we test whether a shift-to-loss strategy is employed on average. We also consider which loss affiliates report the largest difference in unexpected profit.

We first provide evidence that the sign on the coefficient for the tax incentive variable reverses for loss affiliates relative to profitable affiliates, suggesting that these affiliates report a significantly smaller loss than otherwise predicted. This result is consistent with use of a shift-toloss strategy. Next, we find that loss affiliates in jurisdictions in the highest-quartile of statutory tax rates report a more significant difference in the responsiveness of their unexpected profit to tax incentives than do loss affiliates in lower quartiles of STR. Finally, we further verify use of a shift-to-loss strategy by documenting that the profitable affiliates of loss affiliates are less sensitive to the traditional income shifting strategy than are profitable affiliates in all-profitable groups. Together, these findings deepen our understanding of multinational income shifting strategies. 
The estimation methods used in our study allow for the inclusion of unprofitable affiliates in future income shifting studies. Specifically, using return on assets plus one allows for the inclusion of most observable affiliate-years while keeping the traditional log-log specification used in many prior studies. Further, we include several proxies for economic shock that improve the explanatory power of the models when including unprofitable affiliates. We look forward to future research using these methods, for example to explore the methods multinational firms undertake to shift profits to loss affiliates or to consider the costs associated with undertaking such a strategy. 


\section{References}

Aiken, L., and S. West, 1991. Multiple Regression: Testing and Interpreting Interactions. Newbury Park, CA: Sage Publications.

Bernard, A. B., J. B. Jensen, and P. K. Schott, 2008. "Transfer Pricing by U.S.-Based Multinational Firms," Tuck School of Business Working Paper No. 2006-33 and US Census Bureau Center for Economic Studies Paper No. CES-WP- 08-29.

Blouin, J. L., L. A. Robinson and J. K. Seidman, 2015. “Conflicting Transfer Pricing Incentives and the Role of Coordination," University of Pennsylvania, Dartmouth College and University of Virginia working paper.

Chang, S. J., and J. Hong, 2000. "Economic Performance of Group-Affiliated Companies in Korea: Intragroup Resource Sharing and Internal Business Transactions," The Academy of Management Journal 43(3): 429-448.

Claessens, S., and L. Laeven, 2004. "What Drives Bank Competition? Some International Evidence," Journal of Money, Credit and Banking 36(3): 563-583.

Clausing, K.A., 2006. "International Tax Avoidance and U.S. International Trade," National Tax Journal 59(2): 269-287.

Collins, J., D. Kemsley, and M. Lang, 1998. "Cross-Jurisdictional Income Shifting and Earnings Valuation," Journal of Accounting Research 36(2): 209-229.

Desai, M.A., and D. Dharmapala, 2006. “Corporate Tax Avoidance and High-Powered Incentives," Journal of Financial Economics 79(1): 145-179.

De Simone, L., 2016. "Does a Common Set of Accounting Standards Affect Tax-motivated Income Shifting for Multinational Firms?" Journal of Accounting and Economics 61: 145165.

De Simone, L., J. R. Robinson and B. Stomberg, 2014. "Distilling the Reserve for Uncertain Tax Positions: The Revealing Case of Black Liquor," Review of Accounting Studies 19(1): 456472.

Dharmapala, D., 2014. "What Do We Know about Base Erosion and Profit Shifting? A Review of the Empirical Literature," Fiscal Studies 35(4): 421-448.

Dharmapala, D., and N. Riedel, 2013. "Earnings Shocks and Tax-Motivated Income-Shifting: Evidence from European Multinationals,” Journal of Public Economics 97(1): 95-107.

Dorsey \& Whitney LLP, 2006. "Marks \& Spencer v Halsey: The Implications for Cross Border Loss Relief in the European Union,” BNA Inc. 
Dyreng, S. and K. Markle, 2015. "The Effect of Financial Constraints on Tax-Motivated Income Shifting by U.S. Multinationals,” Duke University and University of Iowa working paper.

Edgerton, J., 2010. "Investment Incentives and Corporate Tax Asymmetries," Journal of Public Economics 94(11-12): 936-952.

Erickson, M. M., S. M. Heitzman, and X. F. Zhang, 2012. “Tax-Motivated Loss Shifting," The Accounting Review 88(5): 1657-1682.

Frankel, R., L Litov, 2009. “Earnings persistence," Journal of Accounting and Economics 47(1): 182-190

Gramlich, J. D., P. Limpaphayom, and S. G. Rhee, 2004. “Taxes, Keiretsu Affiliation, and Income Shifting," Journal of Accounting and Economics 37(2): 203-228.

Grubert, H. and J. Mutti, 1991. "Taxes, Tariffs and Transfer Pricing in Multinational Corporate Decision Making," Review of Economics and Statistics 73(2): 285-293.

Guenther, D., and R. Sansing, 2010. "The Effect of Tax-Exempt Investors and Risk on Stock Ownership and Expected Returns," The Accounting Review 85(3): 849-875.

Hanlon, M. and S. Heitzman, 2010. "A Review of Tax Research,” Journal of Accounting and Economics 50(2-3): 127-178.

Hayn, C., 1995. “The Information Content of Losses," Journal of Accounting and Economics 20(1): 125-153.

Hines, J. R. and E. M. Rice, 1994. "Fiscal Paradise: Foreign Tax Havens and American Business,” The Quarterly Journal of Economics 109(1): 149-182.

Hopland, A., P. Lisowsky, M. Marden, and D. Schindler, 2014. "Income Shifting Under Losses," Norwegian School of Economics, University of Illinois and ETH Zurich working paper.

Huizinga, H. and L. Laeven, 2008. "International Profit Shifting within Multinationals: A Multicountry Perspective,” Journal of Public Economics 92(5-6): 1164-1182.

Jacob, J., 1996. "Taxes and Transfer Pricing: Income Shifting and the Volume of Intrafirm Transfers," Journal of Accounting Research 34(2): 201-312.

Khanna, T. and Y. Yafeh, 2005. "Business Groups and Risk Sharing around the World," Journal of Business 78(1): 301-340.

Kim, J. B., and C. H. Yi, 2006. "Ownership Structure, Business Group Affiliation, Listing Status, and Earnings Management: Evidence from Korea," Contemporary Accounting Research 23(2): 427-464. 
Klassen, K. J., M. Lang, and M. Wolfson, 1993. "Geographic Income Shifting by Multinational Corporations in Response to Tax Rate Changes," Journal of Accounting Research 31(Supplement): 140-173.

Klassen, K.J., and S.K Laplante, 2012. “Are U.S. Multinational Corporations Becoming More Aggressive Income Shifters?” Journal of Accounting Research 50(5): 1245-1285.

Mackie-Mason, 1990. “Do Taxes Affect Corporate Financing Decisions?” Journal of Finance 45(5): 1471-1493.

Markle, K., 2015. “A Comparison of the Tax-Motivated Income Shifting of Multinationals in Territorial and Worldwide Countries," forthcoming in Contemporary Accounting Research.

Maydew, E., 1997. "Tax-Induced Earnings Management by Firms with Net Operating Losses." Journal of Accounting Research 35(1): 83-96.

Onji, K. and D. Vera, 2010. "Tax Law Asymmetries and Income Shifting: Evidence from Japanese Capital Keiretsu," The B.E. Journal of Economic Analysis and Policy 10(1): article 4.

Organization for Economic Cooperation and Development (OECD), 2010. "OECD Transfer Pricing Guidelines for Multinational Enterprises and Tax Administrations.” OECD Publishing. http://dx.doi.org/10.1787/tpg-2010-en

Organization for Economic Cooperation and Development (OECD), 2013. Addressing Base Erosion and Profit Shifting, OECD Publishing. http://dx.doi.org/10.1787/9789264192744-en

Organization for Economic Cooperation and Development (OECD), 2015. OECD/G20 Base Erosion and Profit Shifting Project: Measuring and Monitoring BEPS, Action 11: 2015 Final Report, OECD Publishing. http://dx.doi.org/10.1787/9789264241343-en

Overesch, M., 2006. "Transfer Pricing of Intrafirm Sales as a Profit Shifting Channel—Evidence from German Firm Data", Center for European Economic Research Discussion Paper No. 06-084.

Overesch, M., 2009. “The Effects of Multinationals' Profit Shifting Activities on Real Investments," National Tax Journal 62(1): 5-22.

Power, L. and G. Silverstein, 2007. "The Foreign Source Income Repatriation Patters of U.S. Parents in Worldwide Loss," National Tax Journal 60(3): 537-549.

PWC Transfer Pricing Network, 2006. "Comparability: Business comments on the OECD Discussion Draft." 
Saint-Amans, P. and R. Russo, 2013. "What the BEPS Are We Talking About?" OECD Forum 2013.

Scholes, M. S., G. P. Wilson, and M. A. Wolfson, 1992. "Firms' Responses to Anticipated Reductions in Tax Rates: The Tax Reform Act of 1986," Journal of Accounting Research 30(3): 161-185.

Shackelford, D. and T. Shevlin, 2001. "Empirical tax research in accounting." Journal of Accounting and Economics 31(1-3): 321-387.

Signh, K. and A. Mathur, 2013. "BEPS and the Law of Unintended Consequences." TaxNotes, September 16, 2013: 1331-1338

Stock, K., 2013. “Tax Shelters Don't Always Work. Just Ask Amazon.” Bloomberg Businessweek, May 21, 2013.

TPWeek, 2010. Asian countries top aggressiveness tax authorities poll. TPWeek.com. Available at http://www.tpweek.com/Article.aspx?ArticleID=25997632

Weichenrieder, A.J., 2009. "Profit Shifting in the EU: Evidence from Germany," International Tax and Public Finance 16(3): 281-297. 


\section{Appendix \\ Numerical Example}

We present below the calculation of the tax incentive variable $C$ and equilibrium profits shifted using equation (3) for two cases: (1) all affiliates are profitable, and (2) affiliate $i$ is profitable but affiliates $j$ and $k$ report a pre-shifting loss. The change in income shifting behavior between the two cases, given by equation (5), is computed for all three affiliates, assuming the loss affects the expected present value of the tax rate for an affiliate as we model through $\theta$. We make the size of the loss affiliates the same to simplify the exercise. Throughout these examples we use capital as the proxy for economic activity $K$ and hold the cost shifting parameter, $a$, constant at 10 .

Affiliate:

\section{Case 1: all affiliates profitable}

Pre-tax economic profits, $\rho$

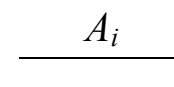

Capital, $K$

\begin{tabular}{|c|c|c|c|}
\hline$A_{i}$ & $A_{j}$ & $A_{k}$ & Total \\
\hline 7.00 & 3.00 & 3.00 & 13.00 \\
\hline 105.00 & 60.00 & 60.00 & 225.00 \\
\hline 0.35 & 0.25 & 0.40 & \\
\hline 1.00 & 1.00 & 1.00 & \\
\hline 4.55 & 2.25 & 1.80 & 8.60 \\
\hline 0.013 & -0.087 & 0.063 & \\
\hline$(0.14)$ & 0.52 & $(0.38)$ & 0.00 \\
\hline 0.00 & 0.02 & 0.01 & 0.04 \\
\hline 4.46 & 2.62 & 1.56 & 8.64 \\
\hline
\end{tabular}

Tax rate, $\tau$

Effect of loss on tax rate, $\theta$

After-tax profits absent shifting

Tax incentive, $C$
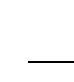

$A_{k}$

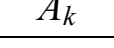

Total

Equilibrium income shifted in (out), $\psi$

Cost of equilibrium income shifting

Reported after-tax profit (loss), $\pi$

\section{Case 2: affiliates $\boldsymbol{j}$ and $\boldsymbol{k}$ have losses and an assumed $\theta$ of one third}

Pre-tax economic profits, $\rho$

Capital, $K$

Tax rate, $\tau$

Effect of loss on tax rate, $\theta$

After-tax profit (loss) absent shifting

Tax incentive updated for effect of losses

Equilibrium income shifted in (out), $\psi$

Cost of equilibrium income shifting

Reported after-tax profit (loss), $\pi$

$\begin{array}{rrrr}7.00 & (3.00) & (3.00) & 1.00 \\ 105.00 & 60.00 & 60.00 & 225.00 \\ 0.35 & 0.25 & 0.40 & \\ 1.00 & 0.33 & 0.33 & \\ 4.55 & (2.75) & (2.60) & (0.80) \\ 0.129 & -0.138 & -0.080 & \\ (1.36) & 0.83 & 0.53 & 0.00 \\ 0.09 & 0.06 & 0.02 & 0.17 \\ 3.58 & (2.05) & (2.17) & (0.64)\end{array}$

\section{Difference between shifting in Case 2 and Case 1}

Equilibrium income shifting, $\psi_{\text {Case 2 }}-\psi_{\text {Case } 1}$

Difference in $\pi$ due to shift-to-loss strategy (applying $\psi_{\text {Case } 1}$ to Case $2 \rho$ and $\theta$ )
0.31

0.91

0.00

0.25

0.78

0.15 
We calculate $C$ as defined by Huizina and Laeven (2008) as the capital-weighted differential statutory tax rate faced by each affiliate. A negative value of $C$ suggests that the group's tax incentives are to shift income into the affiliate (net recipient of shifted profit). For example, in Case 1, Affiliate $j$ has a lower tax rate than the other affiliates, and the resulting value of $C$ is negative, reflecting an incentive to shift income into that affiliate. In contrast, a positive value of $C$ suggests that the group's tax incentives are to shift income out of the affiliate (net provider of shifted profit). For example, in Case 1, the two relatively high tax affiliates $i$ and $k$ have positive values of $C$ and negative equilibrium income shifting. When taking into account the effect of losses in Case 2, the tax incentive becomes stronger (i.e., more positive) for the profitable affiliate $i$ to shift income out relative to Case 1. In Case 1, the tax incentive for the profitable relatively high-tax affiliate $k$ suggests an incentive to shift income out, but when $k$ incurs a loss in Case 2, the equilibrium shifting strategy changes due to a tax incentive to shift income out. As a relatively low-tax affiliate, affiliate $j$ exhibits a tax incentive to receive shifted income in both Case 1 and Case 2. However, the response is larger when affiliate $j$ incurs a loss.

The reported after-tax profit (loss), $\pi$, is calculated as economic profit, $\rho$, plus income shifted, $\psi$, less taxes at rate $\theta \tau$ and the cost of shifting, $a / 2 * \psi^{2} / \rho$. These calculations ignore the costs of changing the income distribution strategy to take advantage of the losses. The difference in $\pi$ due to the implementation of a to shift-to-loss strategy is calculated as the difference between $\pi$ in Case 2 and $\pi$ that would have been reported if a traditional strategy were still employed (i.e., $\rho, \theta$ and $\tau$ in Case 2 coupled with $\psi$ in Case 1).

Comparing the two scenarios reveals two phenomena. First, comparing the equilibrium income shifting of affiliate $j$ across the two cases, the numerical examples demonstrate that more income is shifted into an affiliate when it experiences a loss than when it is a profitable relatively low-tax affiliate. Second, comparing the change in income shifting between Case 1 and Case 2 across loss affiliates with different statutory tax rates, the numerical examples demonstrate that affiliates with relatively higher statutory tax rates (in this example, affiliate $k$ ) reported a larger change in income shifting when moving from profit to loss than affiliates with lower statutory tax rates (here, affiliate $j$ ). This example is consistent with our first hypothesis.

In this example, the difference in profitability from altering the income shifting distribution from that reported in Case 1 to the new optimum reflected in Case 2 creates additional after-tax profits for the group of 0.15 (note, if no income shifting had occurred, the after-tax profits would have been -0.80). If, in Case 2, only affiliate $k$ experiences an economic loss of -3.00 , but affiliate $j$ continued to be profitable as in Case 1, then the benefit of altering the income shifting strategy from Case 1 to the new optimal solution is 0.16 . On the other hand, if only affiliate $j$ experiences the loss, rather than affiliate $k$, the benefit of altering the income shifting strategy from Case 1 to the new optimum declines to 0.06 . This decline reflects that fact that affiliate $j$ was already a relatively low tax affiliate whereas changing from shifting out of affiliate $k$ under the allprofitable case, to shifting into affiliate $k$ when it has a loss yields a much larger improvement in after-tax profits. If the costs of altering the strategy are fixed, at say 0.10 , then the firm in this example would not alter its income shifting strategy in the face of only the low tax-rate affiliate experiencing a loss, whereas it will alter its strategy in the face of the higher tax-rate affiliate experiencing a loss. On average, firms will be more likely to alter their income shifting strategy in response to a loss when the loss arises in a higher tax-rate jurisdiction. This is the basis of hypothesis $\mathrm{H} 2$. 
Table 1: Sample Selection

\begin{tabular}{|c|c|}
\hline \multicolumn{2}{|l|}{ Affiliate Sample Selection } \\
\hline European affiliate-years in Bureau van Dijk's Amadeus database with at least one foreign EU affiliate and not missing earnings & 222,461 \\
\hline Less: Missing NACE code (Amadeus variable $N A C P R I)$ & $(16,733)$ \\
\hline Less: Banks and insurance company (NACE codes 64,65 or 66 ) & $(52,094)$ \\
\hline Less: Group consolidated return on sales ( $P L B T / R E V)$ less than 3 percent & $(54,663)$ \\
\hline Less: Assets less than or equal to zero, or missing (Amadeus variables $T O A S$ and $T F A S$ ) & $(18,648)$ \\
\hline Less: Compensation expense less than zero or equal to zero, or missing (Amadeus variable STAF) & $(15,971)$ \\
\hline Less: Missing Age or a measure of economic shock ( $\triangle G D P, \triangle M a r k e t$ Size $)$ & $(4,338)$ \\
\hline Less: $\mathrm{ROA}+1$ less than or equal to zero & $(271)$ \\
\hline Total affiliate-years used for esimation & 59,743 \\
\hline
\end{tabular}

The affiliated firm sample consists of a total of 59,743 European affiliate-years over the period 2003-2012 with at least one foreign affiliated firm also located in Europe and sufficient data from Amadeus and the European Commission for estimation. Of these, we characterize 11,838 affiliate-years as unprofitable (Loss=1) and 47,905 affiliate-years as profitable $($ Loss $=0)$. 
Table 2: Sample Composition and Measures by Country

\begin{tabular}{|c|c|c|c|}
\hline \multirow[b]{2}{*}{ Country } & \multirow[b]{2}{*}{ Affiliate-Year N } & \multirow[b]{2}{*}{ Group-Year N } & Mean over Sample Period \\
\hline & & & STR \\
\hline Austria & 600 & 335 & 0.25 \\
\hline Bosnia and Herzegovina & 217 & 152 & 0.10 \\
\hline Belgium & 4,839 & 1,782 & 0.34 \\
\hline Bulgaria & 329 & 201 & 0.12 \\
\hline Czech Republic & 2,351 & 1,194 & 0.22 \\
\hline Germany & 5,149 & 1,431 & 0.34 \\
\hline Denmark & 1,070 & 686 & 0.25 \\
\hline Estonia & 703 & 583 & 0.22 \\
\hline Spain & 6,129 & 2,621 & 0.32 \\
\hline Finland & 2,971 & 1,392 & 0.26 \\
\hline France & 7,654 & 2,498 & 0.33 \\
\hline United Kingdom & 2,518 & 1,113 & 0.29 \\
\hline Croatia & 836 & 383 & 0.20 \\
\hline Hungary & 1,865 & 845 & 0.17 \\
\hline Ireland & 154 & 114 & 0.13 \\
\hline Italy & 8,376 & 3,107 & 0.34 \\
\hline Luxembourg & 156 & 131 & 0.29 \\
\hline Netherlands & 316 & 238 & 0.28 \\
\hline Norway & 2,341 & 1,294 & 0.28 \\
\hline Poland & 2,111 & 1,308 & 0.20 \\
\hline Portugal & 1,157 & 770 & 0.26 \\
\hline Romania & 1,287 & 990 & 0.18 \\
\hline Serbia & 475 & 382 & 0.10 \\
\hline Sweden & 4,693 & 2,044 & 0.27 \\
\hline Slovenia & 375 & 234 & 0.22 \\
\hline Slovakia & 1,071 & 757 & 0.19 \\
\hline All Countries & 59,743 & 26,585 & 0.24 \\
\hline
\end{tabular}

The sample consists of a total of 59,743 European affiliate-years 2003-2012. This table provides the number of affiliate-year observations by country, the number of group-years with a presence in each country, as well as average country-year measures by country over the sample period. STR is the affiliate's statutory tax rate. 
Table 3: Descriptive Statistics

\begin{tabular}{|c|c|c|c|c|c|c|c|}
\hline \multicolumn{8}{|c|}{ Panel A: All Affiliates } \\
\hline & & $\mathrm{N}$ & Mean & $\mathrm{p} 25$ & Median & $\mathrm{p} 75$ & Std \\
\hline \multirow{14}{*}{$\begin{array}{l}\text { Income } \\
\text { Prediction } \\
\text { Variables }\end{array}$} & EBIT & 59,743 & $5,732,312$ & 30,663 & 431,925 & $2,394,419$ & $21,907,060$ \\
\hline & ROA & 59,743 & 0.084 & 0.012 & 0.062 & 0.144 & 0.256 \\
\hline & TangibleAssets & 59,743 & $20,033,883$ & 91,003 & 733,876 & $5,640,460$ & $79,637,921$ \\
\hline & CompExp & 59,743 & $10,881,487$ & 454,949 & $1,628,638$ & $5,987,287$ & $33,325,885$ \\
\hline & $\ln (\mathrm{EBIT})$ & 47,864 & 13.64 & 12.21 & 13.64 & 15.08 & 2.197 \\
\hline & $\ln (\mathrm{ROA})$ & 47,864 & -2.569 & -3.173 & -2.429 & -1.766 & 1.195 \\
\hline & $\ln (\mathrm{ROA}+1)$ & 59,743 & 0.063 & 0.011 & 0.060 & 0.135 & 0.209 \\
\hline & $\ln$ (TangibleAssets) & 59,743 & 13.49 & 11.42 & 13.51 & 15.55 & 2.885 \\
\hline & $\ln ($ CompExp $)$ & 59,743 & 14.29 & 13.03 & 14.30 & 15.61 & 2.040 \\
\hline & IndustryROA & 59,743 & 0.079 & 0.041 & 0.069 & 0.110 & 0.077 \\
\hline & Age & 59,743 & 4.595 & 2.000 & 4.000 & 7.000 & 2.701 \\
\hline & $\Delta \mathrm{GDP}$ & 59,743 & 0.025 & 0.005 & 0.030 & 0.051 & 0.043 \\
\hline & $\Delta$ MarketSize & 59,743 & 0.141 & -0.022 & 0.020 & 0.194 & 1.006 \\
\hline & Loss & 59,743 & 0.198 & 0.000 & 0.000 & 0.000 & 0.399 \\
\hline \multirow{3}{*}{$\begin{array}{l}\text { Tax } \\
\text { Variables }\end{array}$} & $\mathrm{C}$ & 56,087 & -0.004 & -0.007 & 0.000 & 0.012 & 0.047 \\
\hline & STR & 59,743 & 0.286 & 0.255 & 0.300 & 0.333 & 0.063 \\
\hline & HighSTR & 59,743 & 0.195 & 0.000 & 0.000 & 0.000 & 0.396 \\
\hline \multirow{3}{*}{$\begin{array}{l}\text { Other Firm } \\
\text { Attributes }\end{array}$} & Sales & 56,941 & $87,263,268$ & $2,614,931$ & $10,152,718$ & $42,864,824$ & $276,900,000$ \\
\hline & ROS & 56,941 & 0.183 & 0.011 & 0.052 & 0.110 & 29.26 \\
\hline & Assets & 59,743 & $111,100,000$ & $2,198,834$ & $8,599,044$ & $38,313,862$ & $417,100,000$ \\
\hline
\end{tabular}

The sample consists of a total of 59,743 European affiliate-years 2003-2012. EBIT is earnings before interest and taxes. ROA is EBIT scaled by Assets, where Assets is total assets. TangibleAssets is total fixed assets. CompExp is compensation expense. $\ln (E B I T)$ is the natural $\log$ of $E B I T$, $\ln (R O A)$ is the natural log of $R O A$, $\ln (R O A+1)$ is the natural $\log$ of $R O A$ plus one, $\ln$ (TangibleAssets) is the natural log of TangibleAssets, and $\ln ($ CompExp) is the natural log of CompExp. IndustryROA is country-yearindustry median ROA for all observable companies in Amadeus. Age equals year $t$ minus the year the affiliate first appears in the Amadeus database. $\triangle G D P$ is $G D P$ in year $t$ less $G D P$ in year $t-1$, scaled by GDP in year $t-1$. $\Delta M k t$ Size is the country-industry-year sum of affiliate and standalone firm sales in year $t$ less the sum in year $t$ - 1 , scaled by $1,000,000$. Loss is set to 1 if affiliate $E B I T$ is less than zero. $C$ is the capital-weighted differential statutory tax rate between the affiliate and all related affiliates in the same group-year. STR is statutory tax rate. ROS is EBIT scaled by Sales, where Sales is operating revenues (net). 
Table 3: Descriptive Statistics (cont.)

\begin{tabular}{|c|c|c|c|c|c|c|c|}
\hline \multicolumn{8}{|c|}{ Panel B: Unprofitable Affiliates ( $L O S S=1)$} \\
\hline & & $\mathrm{N}$ & Mean & $\mathrm{p} 25$ & Median & $\mathrm{p} 75$ & Std \\
\hline Income & EBIT & 11,838 & $-1,628,290$ & $-1,183,380$ & $-283,400$ & $-72,431$ & $3,317,939$ \\
\hline Prediction & $\mathrm{ROA}$ & 11,838 & -0.116 & -0.146 & -0.053 & -0.015 & 0.162 \\
\hline \multirow[t]{12}{*}{ Variables } & TangibleAssets & 11,838 & $11,508,048$ & 48,517 & 381,806 & $2,994,710$ & $56,721,695$ \\
\hline & CompExp & 11,838 & $7,719,880$ & 248,466 & 915,665 & $3,732,362$ & $27,192,721$ \\
\hline & $\ln (\mathrm{EBIT})$ & - & . & . & . & . & . \\
\hline & $\ln (\mathrm{ROA})$ & - & . & . & . & - & . \\
\hline & $\ln (\mathrm{ROA}+1)$ & 11,838 & -0.156 & -0.157 & -0.054 & -0.015 & 0.328 \\
\hline & $\ln$ (TangibleAssets) & 11,838 & 12.85 & 10.79 & 12.85 & 14.91 & 2.835 \\
\hline & $\ln ($ CompExp $)$ & 11,838 & 13.75 & 12.42 & 13.73 & 15.13 & 2.125 \\
\hline & IndustryROA & 11,838 & 0.041 & 0.010 & 0.047 & 0.079 & 0.082 \\
\hline & Age & 11,838 & 4.397 & 2.000 & 4.000 & 7.000 & 2.808 \\
\hline & $\triangle \mathrm{GDP}$ & 11,838 & 0.022 & 0.004 & 0.027 & 0.048 & 0.045 \\
\hline & $\Delta$ MarketSize & 11,838 & 0.080 & -0.028 & 0.011 & 0.151 & 0.587 \\
\hline & Loss & 11,838 & 1.000 & 1.000 & 1.000 & 1.000 & 0.000 \\
\hline Tax & $\mathrm{C}$ & 11,038 & -0.006 & -0.010 & 0.000 & 0.011 & 0.047 \\
\hline \multirow[t]{2}{*}{ Variables } & STR & 11,838 & 0.282 & 0.250 & 0.300 & 0.333 & 0.063 \\
\hline & HighSTR & 11,838 & 0.183 & 0.000 & 0.000 & 0.000 & 0.387 \\
\hline Other Firm & Sales & 11,249 & $48,147,579$ & 897,290 & $3,689,851$ & $16,669,834$ & $200,200,000$ \\
\hline \multirow[t]{2}{*}{ Attributes } & ROS & 11,249 & -0.993 & -0.226 & -0.072 & -0.022 & 10.212 \\
\hline & Assets & 11,838 & $112,400,000$ & $1,243,720$ & $5,297,559$ & $26,031,452$ & $450,700,000$ \\
\hline
\end{tabular}

We characterize 11,838 affiliate-years as unprofitable $($ Loss $=1)$. All variables are as defined in Panel A. 
Table 3: Descriptive Statistics (cont.)

\begin{tabular}{|c|c|c|c|c|c|c|c|}
\hline \multicolumn{8}{|c|}{ Panel C: Profitable Affiliates $(L O S S=0)$} \\
\hline & & $\mathrm{N}$ & Mean & $\mathrm{p} 25$ & Median & $\mathrm{p} 75$ & Std \\
\hline Income & EBIT & 47,905 & $7,551,221$ & 200,083 & 835,419 & $3,543,662$ & $24,064,482$ \\
\hline Prediction & ROA & 47,905 & 0.133 & 0.042 & 0.088 & 0.171 & 0.251 \\
\hline \multirow[t]{12}{*}{ Variables } & TangibleAssets & 47,905 & $22,140,737$ & 106,836 & 853,682 & $6,619,595$ & $84,214,451$ \\
\hline & CompExp & 47,905 & $11,662,765$ & 529,412 & $1,832,453$ & $6,734,217$ & $34,630,520$ \\
\hline & $\ln (\mathrm{EBIT})$ & 47,864 & 13.64 & 12.21 & 13.64 & 15.08 & 2.197 \\
\hline & $\ln (\mathrm{ROA})$ & 47,864 & -2.569 & -3.173 & -2.429 & -1.766 & 1.195 \\
\hline & $\ln (\mathrm{ROA}+1)$ & 47,905 & 0.117 & 0.041 & 0.084 & 0.158 & 0.114 \\
\hline & $\ln$ (TangibleAssets) & 47,905 & 13.64 & 11.58 & 13.66 & 15.71 & 2.876 \\
\hline & $\ln ($ CompExp) & 47,905 & 14.43 & 13.18 & 14.42 & 15.72 & 1.996 \\
\hline & IndustryROA & 47,905 & 0.088 & 0.048 & 0.074 & 0.115 & 0.072 \\
\hline & Age & 47,905 & 4.644 & 2.000 & 4.000 & 7.000 & 2.671 \\
\hline & $\triangle \mathrm{GDP}$ & 47,905 & 0.026 & 0.005 & 0.031 & 0.053 & 0.043 \\
\hline & $\Delta$ MarketSize & 47,905 & 0.156 & -0.020 & 0.023 & 0.203 & 1.084 \\
\hline & Loss & 47,905 & 0.000 & 0.000 & 0.000 & 0.000 & 0.000 \\
\hline Tax & $\mathrm{C}$ & 45,049 & -0.004 & -0.006 & 0.000 & 0.013 & 0.047 \\
\hline \multirow[t]{2}{*}{ Variables } & STR & 47,905 & 0.287 & 0.260 & 0.300 & 0.333 & 0.063 \\
\hline & HighSTR & 47,905 & 0.198 & 0.000 & 0.000 & 0.000 & 0.398 \\
\hline Other Firm & Sales & 45,692 & $96,893,233$ & $3,492,415$ & $12,623,290$ & $50,529,496$ & $291,900,000$ \\
\hline \multirow[t]{2}{*}{ Attributes } & ROS & 45,692 & 0.473 & 0.036 & 0.071 & 0.130 & 32.26 \\
\hline & Assets & 47,905 & $110,800,000$ & $2,549,984$ & $9,635,821$ & $41,308,135$ & $408,400,000$ \\
\hline
\end{tabular}

We characterize 47,905 affiliate-years as being profitable $($ Loss $=0)$. All variables are as defined in Panel A. 
Table 4: Correlations

\begin{tabular}{|c|c|c|c|c|c|c|c|c|c|c|c|c|c|c|}
\hline & & $(1)$ & $(2)$ & (3) & $(4)$ & $(5)$ & $(6)$ & $(7)$ & $(8)$ & $(9)$ & $(10)$ & $(11)$ & $(12)$ & $(13)$ \\
\hline (1) & $\ln (\mathrm{EBIT})$ & $\begin{array}{r}\mathbf{1 . 0 0 0} \\
(0.00)\end{array}$ & & & & & & & & & & & & \\
\hline (2) & $\ln (\mathrm{ROA})$ & $\begin{array}{c}\mathbf{0 . 3 6 4} \\
(0.00)\end{array}$ & $\begin{array}{r}\mathbf{1 . 0 0 0} \\
(0.00)\end{array}$ & & & & & & & & & & & \\
\hline (3) & $\ln (\mathrm{ROA}+1)$ & $\begin{array}{r}\mathbf{0 . 2 1 0} \\
(0.00)\end{array}$ & $\begin{array}{r}\mathbf{0 . 7 8 5} \\
(0.00)\end{array}$ & $\begin{array}{r}\mathbf{1 . 0 0 0} \\
(0.00)\end{array}$ & & & & & & & & & & \\
\hline (4) & $\ln$ (TangibleAssets) & $\begin{array}{r}\mathbf{0 . 6 6 3} \\
(0.00)\end{array}$ & $\begin{array}{r}\mathbf{- 0 . 1 4 3} \\
(0.00)\end{array}$ & $\begin{array}{r}\mathbf{0 . 0 2 8} \\
(0.00)\end{array}$ & $\begin{array}{r}\mathbf{1 . 0 0 0} \\
(0.00)\end{array}$ & & & & & & & & & \\
\hline (5) & $\ln ($ CompExp) & $\begin{array}{r}\mathbf{0 . 7 2 8} \\
(0.00)\end{array}$ & $\begin{array}{r}\mathbf{0 . 0 1 5} \\
(0.00)\end{array}$ & $\begin{array}{r}\mathbf{0 . 0 7 8} \\
(0.00)\end{array}$ & $\begin{array}{c}\mathbf{0 . 5 9 2} \\
(0.00)\end{array}$ & $\begin{array}{r}1.000 \\
(0.00)\end{array}$ & & & & & & & & \\
\hline (6) & IndustryROA & $\begin{array}{r}\mathbf{0 . 1 7 9} \\
(0.00)\end{array}$ & $\begin{array}{r}\mathbf{0 . 3 1 6} \\
(0.00)\end{array}$ & $\begin{array}{r}\mathbf{0 . 2 9 7} \\
(0.00)\end{array}$ & $\begin{array}{r}\mathbf{0 . 0 2 5} \\
(0.00)\end{array}$ & $\begin{array}{r}\mathbf{0 . 1 1 0} \\
(0.00)\end{array}$ & $\begin{array}{r}\mathbf{1 . 0 0 0} \\
(0.00)\end{array}$ & & & & & & & \\
\hline (7) & $\ln ($ Age $)$ & $\begin{array}{r}\mathbf{0 . 1 1 1} \\
(0.00)\end{array}$ & $\begin{array}{r}-\mathbf{- 0 . 0 2 4} \\
(0.00)\end{array}$ & $\begin{array}{r}\mathbf{0 . 0 4 2} \\
(0.00)\end{array}$ & $\begin{array}{r}\mathbf{0 . 1 0 2} \\
(0.00)\end{array}$ & $\begin{array}{r}\mathbf{0 . 1 5 4} \\
(0.00)\end{array}$ & $\begin{array}{r}\mathbf{- 0 . 0 3 5} \\
(0.00)\end{array}$ & $\begin{array}{r}\mathbf{1 . 0 0 0} \\
(0.00)\end{array}$ & & & & & & \\
\hline (8) & $\Delta \mathrm{GDP}$ & $\begin{array}{r}-0.003 \\
(0.51)\end{array}$ & $\begin{array}{r}\mathbf{0 . 0 5 7} \\
(0.00)\end{array}$ & $\begin{array}{r}\mathbf{0 . 0 5 3} \\
(0.00)\end{array}$ & $\begin{array}{c}0.004 \\
(0.28)\end{array}$ & $\begin{array}{r}\mathbf{- 0 . 0 3 7} \\
(0.00)\end{array}$ & $\begin{array}{r}\mathbf{0 . 1 1 9} \\
(0.00)\end{array}$ & $\begin{array}{r}-\mathbf{0 . 1 7 3} \\
(0.00)\end{array}$ & $\begin{array}{r}1.000 \\
(0.00)\end{array}$ & & & & & \\
\hline (9) & $\Delta$ MarketSize & $\begin{array}{r}\mathbf{0 . 0 5 6} \\
(0.00)\end{array}$ & $\begin{array}{l}0.007 \\
(0.12)\end{array}$ & $\begin{array}{r}\mathbf{0 . 0 1 5} \\
(0.00)\end{array}$ & $\begin{array}{l}\mathbf{0 . 0 6 2} \\
(0.00)\end{array}$ & $\begin{array}{c}\mathbf{0 . 0 2 2} \\
(0.00)\end{array}$ & $\begin{array}{r}\mathbf{0 . 0 3 1} \\
(0.00)\end{array}$ & $\begin{array}{r}\mathbf{- 0 . 1 1 5} \\
(0.00)\end{array}$ & $\begin{array}{r}\mathbf{0 . 1 5 9} \\
(0.00)\end{array}$ & $\begin{array}{r}\mathbf{1 . 0 0 0} \\
(0.00)\end{array}$ & & & & \\
\hline (10) & Loss & $\cdot(1.00)$ & $(1.00)$ & $\begin{array}{c}\mathbf{- 0 . 5 2 0} \\
(0.00)\end{array}$ & $\begin{array}{r}\mathbf{- 0 . 1 0 9} \\
(0.00)\end{array}$ & $\begin{array}{c}-\mathbf{- 0 . 1 3 3} \\
(0.00)\end{array}$ & $\begin{array}{c}-\mathbf{- 0 . 2 4 1} \\
(0.00)\end{array}$ & $\begin{array}{c}\mathbf{- 0 . 0 5 2} \\
(0.00)\end{array}$ & $\begin{array}{c}\mathbf{- 0 . 0 4 1} \\
(0.00)\end{array}$ & $\begin{array}{c}-\mathbf{- 0 . 0 3 0} \\
(0.00)\end{array}$ & $\begin{array}{r}\mathbf{1 . 0 0 0} \\
(0.00)\end{array}$ & & & \\
\hline (11) & $\mathrm{C}$ & $\begin{array}{r}\mathbf{0 . 0 5 6} \\
(0.00)\end{array}$ & $\begin{array}{c}-\mathbf{0 . 0 6 8} \\
(0.00)\end{array}$ & $\begin{array}{r}-\mathbf{0 . 0 1 0} \\
(0.02)\end{array}$ & $\begin{array}{c}\mathbf{0 . 0 3 2} \\
(0.00)\end{array}$ & $\begin{array}{l}\mathbf{0 . 1 2 1} \\
(0.00)\end{array}$ & $\begin{array}{r}-\mathbf{0 . 0 4 2} \\
(0.00)\end{array}$ & $\begin{array}{r}\mathbf{0 . 0 3 7} \\
(0.00)\end{array}$ & $\begin{array}{c}-\mathbf{0 . 1 4 4} \\
(0.00)\end{array}$ & $\begin{array}{r}\mathbf{0 . 0 6 5} \\
(0.00)\end{array}$ & $\begin{array}{c}-\mathbf{0 . 0 1 6} \\
(0.00)\end{array}$ & $\begin{array}{r}1.000 \\
(0.00)\end{array}$ & & \\
\hline (12) & STR & $\begin{array}{r}\mathbf{0 . 1 0 4} \\
(0.00)\end{array}$ & $\begin{array}{r}\mathbf{- 0 . 0 7 8} \\
(0.00)\end{array}$ & $\begin{array}{r}-\mathbf{0 . 0 1 3} \\
(0.00)\end{array}$ & $\begin{array}{r}\mathbf{0 . 0 5 6} \\
(0.00)\end{array}$ & $\begin{array}{r}\mathbf{0 . 1 7 2} \\
(0.00)\end{array}$ & $\begin{array}{r}-\mathbf{0 . 0 6 7} \\
(0.00)\end{array}$ & $\begin{array}{r}\mathbf{- 0 . 1 4 3} \\
(0.00)\end{array}$ & $\begin{array}{r}\mathbf{- 0 . 0 7 6} \\
(0.00)\end{array}$ & $\begin{array}{r}\mathbf{0 . 1 2 3} \\
(0.00)\end{array}$ & $\begin{array}{r}-\mathbf{0 . 0 3 4} \\
(0.00)\end{array}$ & $\begin{array}{r}\mathbf{0 . 6 1 2} \\
(0.00)\end{array}$ & $\begin{array}{r}\mathbf{1 . 0 0 0} \\
(0.00)\end{array}$ & \\
\hline (13) & HighSTR & $\begin{array}{c}\mathbf{0 . 0 4 7} \\
(0.00)\end{array}$ & $\begin{array}{c}\mathbf{- 0 . 0 4 8} \\
(0.00)\end{array}$ & $\begin{array}{r}\mathbf{- 0 . 0 1 7} \\
(0.00)\end{array}$ & $\begin{array}{r}\mathbf{0 . 0 2 9} \\
(0.00) \\
\end{array}$ & $\begin{array}{r}\mathbf{0 . 0 7 9} \\
(0.00) \\
\end{array}$ & $\begin{array}{r}\mathbf{- 0 . 0 4 9} \\
(0.00)\end{array}$ & $\begin{array}{r}\mathbf{- 0 . 0 0 4} \\
(0.32)\end{array}$ & $\begin{array}{r}\mathbf{- 0 . 0 6 9} \\
(0.00) \\
\end{array}$ & $\begin{array}{r}\mathbf{0 . 0 8 6} \\
(0.00) \\
\end{array}$ & $\begin{array}{r}-\mathbf{0 . 0 1 5} \\
(0.00)\end{array}$ & $\begin{array}{r}\mathbf{0 . 3 1 3} \\
(0.00)\end{array}$ & $\begin{array}{r}\mathbf{0 . 5 0 9} \\
(0.00)\end{array}$ & $\begin{array}{r}1.000 \\
(0.00) \\
\end{array}$ \\
\hline
\end{tabular}

In denotes the natural log of the term in parentheses. EBIT is earnings before interest and taxes. ROA is EBIT scaled by Assets, where Assets is total assets. TangibleAssets is total fixed assets. CompExp is compensation expense. IndustryROA is country-year-industry median ROA of all observable companies in Amadeus. Age equals year $t$ minus the year the affiliate first appears in the Amadeus database. $\triangle G D P$ is GDP in year $t$ less GDP in year $t-1$, scaled by GDP in year $t-1$. $\triangle M k t$ Size is the country-industry-year sum of all firm sales in year $t$ less the sum in year $t$-1, scaled by 1,000,000. Loss is set to 1 if EBIT is less than zero. $C$ is a capital-weighted differential statutory tax rate between the affiliate and all related affiliates in the same group-year. STR is the country-year statutory tax rate. 
Table 5: Tests Using the Tax Incentive Variable C

Panel A: Income Shifting Model

$\ln (\pi)=\beta_{0}+\beta_{1}{ }^{*} \ln ($ TangibleAssets $)+\beta_{2}{ }^{*} \ln ($ CompExp $)+\beta_{3}{ }^{*}$ IndustryROA $+\beta_{4}{ }^{*} C$

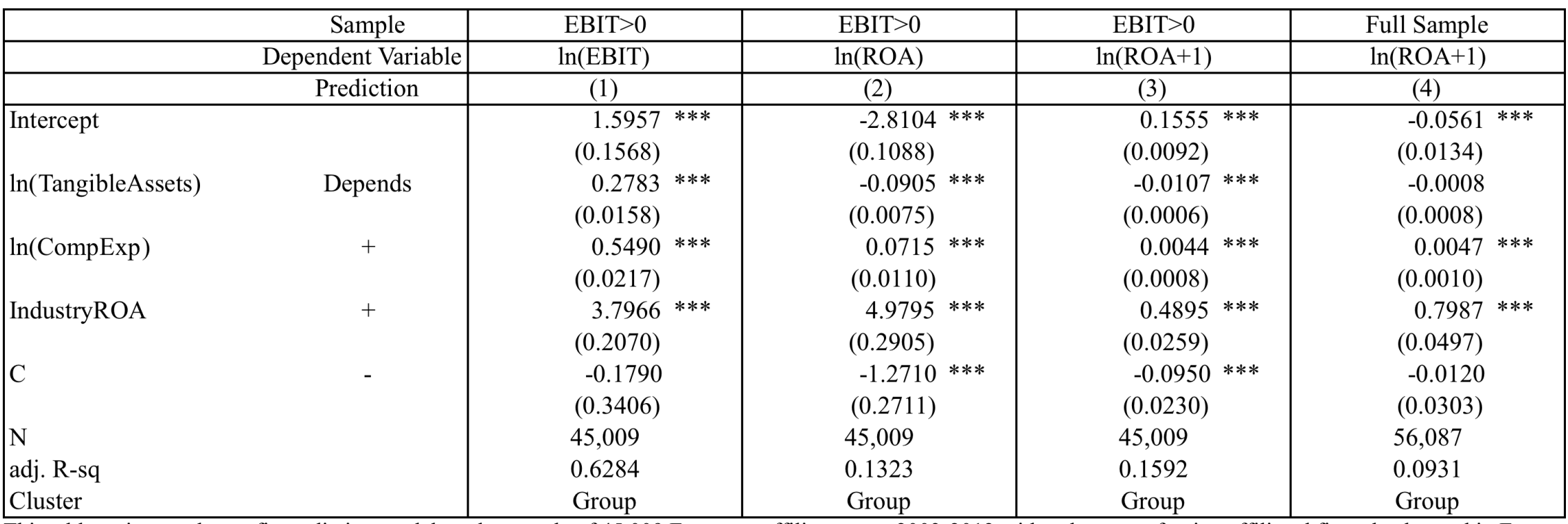

This table estimates the profit prediction model on the sample of 45,009 European affiliate-years 2003-2012 with at least one foreign affiliated firm also located in Europe and sufficient data from Amadeus and the European Commission for estimation for which EBIT is greater than zero in Columns (1)-(3) as well as on the sample of 56,087 affiliates with sufficient data for estimation in Column (4). EBIT is earnings before interest and taxes. $\ln (E B I T)$ is the natural log of EBIT. ROA is EBIT scaled by Assets, where Assets is total assets. $\ln (R O A)$ is the natural $\log$ of $R O A \cdot \ln (R O A+1)$ is the natural $\log$ of $R O A$ plus 1 . $\ln ($ TangibleAssets $)$ is the natural log of total fixed assets. $\ln ($ CompExp) is the natural $\log$ of compensation expense. IndustryROA is a measure of country-year-industry median ROA. $C$ is a capital-weighted differential statutory tax rate between the affiliate and all related affiliates in the same group-year. All specifications report standard errors clustered by group. $*, * *$, and $* * *$ represent one-tailed statistical significance at the $10 \%, 5 \%$, and $1 \%$ levels, respectively. 
Table 5: Tests Using the Tax Incentive Variable C

Panel B: Test of the Effect of Losses on Tax-Motivated Income Shifting (H1)

$\ln ($ ROA +1$)=\beta_{0}+\beta_{1} * \ln ($ TangibleAssets $)+\beta_{2} * \ln ($ CompExp $)+\beta_{3} *$ IndustryROA $+\beta_{4} *$ Shock $+\beta_{5}{ }^{*} C+\beta_{6} *$ Loss $+\beta_{7} *$ Loss $^{*} C$

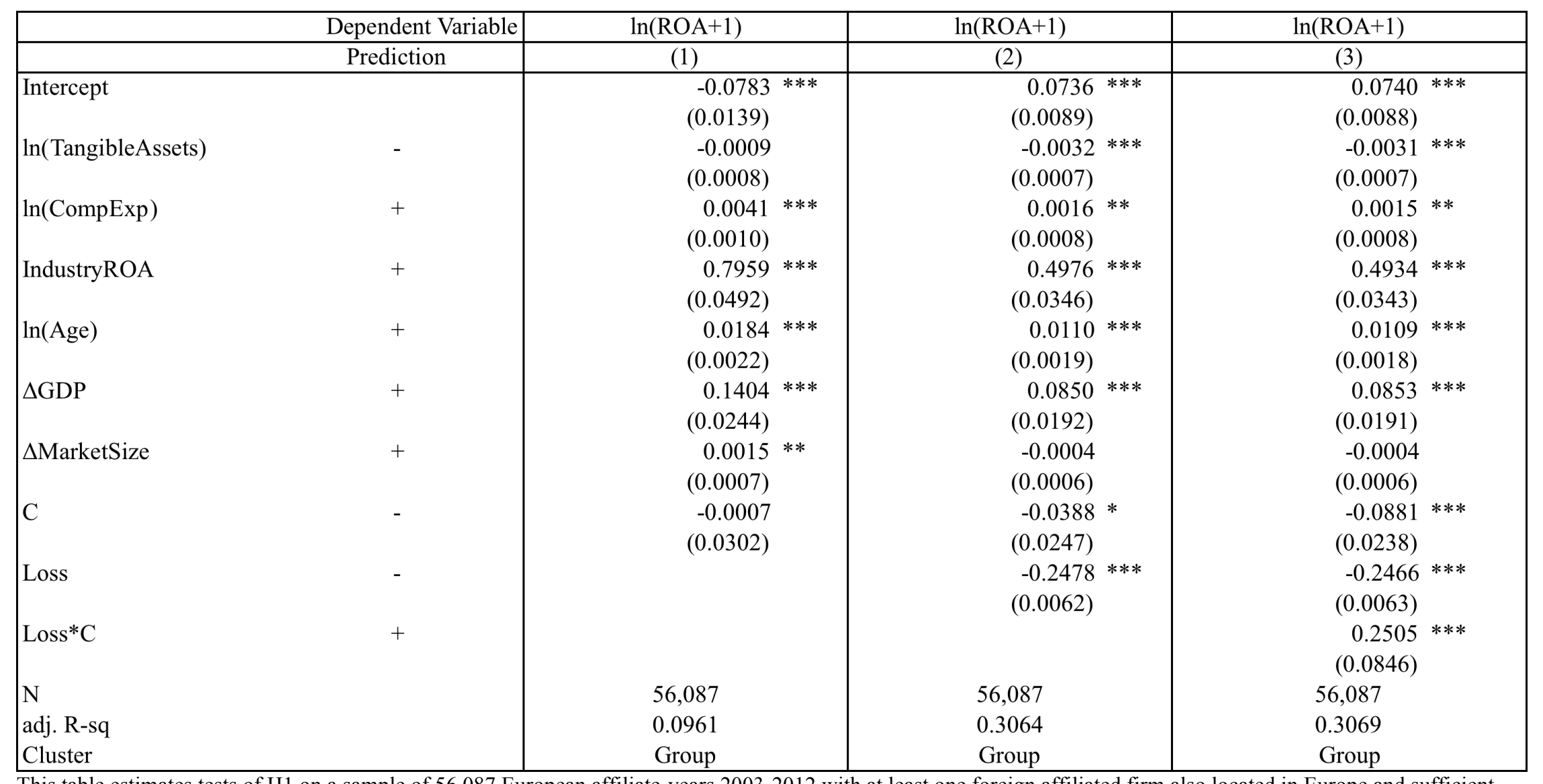

This table estimates tests of H1 on a sample of 56,087 European affiliate-years 2003-2012 with at least one foreign affiliated firm also located in Europe and sufficient data from Amadeus and the European Commission for estimation. The dependent variable is $\ln (R O A+1)$, the natural log of EBIT scaled by $A s s e t s$ plus 1 .

$\ln$ (TangibleAssets) is that natural log of total fixed assets. $\ln ($ CompExp) is the natural log of compensation expense. IndustryROA is a measure of country-year-industry median ROA. $\ln (A g e)$ is the natural log of Age, measured as year $t$ minus the year the affiliate first appears in the Amadeus database. $\triangle G D P$ is $G D P$ in year $t$ less $G D P$ in year $t-1$, scaled by GDP in year $t-1$. $\Delta M k t$ Size is the country-industry-year sum of all affiliate and standalone firm sales in year $t$ less the sum in year $t-1$, scaled by $1,000,000 . C$ is the capital-weighted average differential statutory tax rate between the affiliate and all other related affiliates in the same group-year. Loss is set to 1 if affiliate EBIT is less than zero. All specifications report standard errors clustered by group. *, **, and *** represent one-tailed statistical significance at the $10 \%, 5 \%$, and $1 \%$ levels, respectively. 
Table 6: Test of the Effect of Losses on Tax-Motivated Income Shifting Using the Tax Incentive Variable STR (H1)

$\ln (R O A+1)=\beta_{0}+\beta_{1} * \ln ($ TangibleAssets $)+\beta_{2} * \ln ($ CompExp $)+\beta_{3}{ }^{*}$ IndustryROA $+\beta_{4}{ }^{*}$ Shock $+\beta_{5}{ }^{*}$ STR $+\beta_{6}{ }^{*}$ Loss $+\beta_{7}{ }^{*}$ Loss ${ }^{*}$ STR

\begin{tabular}{|c|c|c|c|c|}
\hline & Dependent Variable & $\ln (\mathrm{ROA}+1)$ & $\ln (\mathrm{ROA}+1)$ & $\ln (\mathrm{ROA}+1)$ \\
\hline & Prediction & $(1)$ & $(2)$ & (3) \\
\hline Intercept & & $\begin{array}{l}-0.0857^{* * *} \\
(0.0136)\end{array}$ & $\begin{array}{l}0.0720^{* * *} \\
(0.0087)\end{array}$ & $\begin{array}{l}0.0732 \\
(0.0087)\end{array}$ \\
\hline $\ln$ (TangibleAssets) & - & $\begin{array}{r}-0.0008 \\
(0.0008)\end{array}$ & $\begin{array}{l}-0.0029 * * * \\
(0.0006)\end{array}$ & $\begin{array}{l}-0.0028 * * * \\
(0.0006)\end{array}$ \\
\hline $\ln ($ CompExp $)$ & + & $\begin{array}{l}0.0044 \text { *** } \\
(0.0010)\end{array}$ & $\begin{array}{l}0.0017 \text { ** } \\
(0.0008)\end{array}$ & $\begin{array}{l}0.0016 \text { ** } \\
(0.0007)\end{array}$ \\
\hline IndustryROA & + & $\begin{array}{l}0.7950 \quad * * * \\
(0.0480)\end{array}$ & $\begin{array}{l}0.48900^{* * *} \\
(0.0337)\end{array}$ & $\begin{array}{r}0.4843 \\
(0.0338)\end{array}$ \\
\hline $\ln ($ Age $)$ & + & $\begin{array}{l}0.0189 * * * \\
(0.0021)\end{array}$ & $\begin{array}{r}0.0092 \\
(0.0018)\end{array}$ & $\begin{array}{r}0.0090 \\
(0.0018)\end{array}$ \\
\hline$\Delta \mathrm{GDP}$ & + & $\begin{array}{l}0.1409 \text { *** } \\
(0.0242)\end{array}$ & $\begin{array}{l}0.0823 \\
(0.0193)\end{array}$ & $\begin{array}{l}0.0828 * * * \\
(0.0192)\end{array}$ \\
\hline$\Delta$ MarketSize & + & $\begin{array}{l}0.0013 \text { ** } \\
(0.0007)\end{array}$ & $\begin{array}{r}-0.0002 \\
(0.0007)\end{array}$ & $\begin{array}{r}-0.0001 \\
(0.0007)\end{array}$ \\
\hline STR & - & $\begin{array}{r}0.0306 \\
(0.0236)\end{array}$ & $\begin{array}{l}-0.0401 * * \\
(0.0187)\end{array}$ & $\begin{array}{l}-0.0730 * * * \\
(0.0190)\end{array}$ \\
\hline Loss & - & & $\begin{array}{l}-0.2501 * * * \\
(0.0060)\end{array}$ & $\begin{array}{l}-0.2498 * * * \\
(0.0061)\end{array}$ \\
\hline Loss*STR & + & & & $\begin{array}{l}0.1641 \\
(0.0800)\end{array}$ \\
\hline $\mathrm{N}$ & & 59,743 & 59,743 & 59,743 \\
\hline adj. R-sq & & 0.0935 & 0.3041 & 0.3045 \\
\hline Cluster & & Group & Group & Group \\
\hline
\end{tabular}

This table estimates tests of $\mathrm{H} 1$ on a sample of 59,743 European affiliate-years 2003-2012 with at least one foreign affiliated firm also located in Europe and sufficient data from Amadeus and the European Commission for estimation. The dependent variable is $\ln (R O A+1)$, the natural log of EBIT scaled by Assets plus 1 . $\ln$ (TangibleAssets) is that natural $\log$ of total fixed assets. $\ln ($ CompExp) is the natural $\log$ of compensation expense. IndustryROA is a measure of country-year-industry median ROA. $\ln (\mathrm{Age})$ is the natural $\log$ of $A g e$, measured as year $t$ minus the year the affiliate first appears in the Amadeus database. $\triangle G D P$ is GDP in year $t$ less GDP in year $t-1$, scaled by GDP in year $t-1$. $\Delta$ MktSize is the country-industry-year sum of all affiliate and standalone firm sales in year $t$ less the sum in year $t-1$, scaled by $1,000,000$. STR is the mean-centered country-year statutory tax rate. Loss is set to 1 if affiliate $E B I T$ is less than zero. All specifications report standard errors clustered by group. ${ }^{* *}$, and ${ }^{* * *}$ represent one-tailed statistical significance at the $10 \%, 5 \%$, and $1 \%$ levels, respectively. 
Table 7: Tests of the Effect of High Tax Rates on the Shift-to-Loss Strategy (H2)

$$
\begin{gathered}
\ln (\text { ROA }+1)=\beta_{0}+\beta_{1} * \ln (\text { TangibleAssets })+\beta_{2} * \ln (\text { CompExp })+\beta_{3} * \text { IndustryROA }+\beta_{4} * \text { Shock }+ \\
\beta_{5} * \text { TaxIncentive }+\beta_{6} * \text { Loss }+\beta_{7} * \text { Loss } * \text { TaxIncentive }+\beta_{8} * \text { HighSTR }+\beta_{9} * \text { HighSTR } * \text { Loss }+ \\
\beta_{10} * \text { HighSTR } * \text { TaxIncentive }+\beta_{11} * \text { HighSTR } * \text { Loss } * \text { TaxIncentive }
\end{gathered}
$$

\begin{tabular}{|c|c|c|c|}
\hline & Incentive $=$ & $\mathrm{C}$ & STR \\
\hline Deper & ent Variable & $\ln (\mathrm{ROA}+1)$ & $\ln (\mathrm{ROA}+1)$ \\
\hline & Prediction & $(1)$ & $(2)$ \\
\hline Intercept & + & $\begin{array}{l}0.0748 * * * \\
(0.0088)\end{array}$ & $\begin{array}{l}0.0727 \text { *** } \\
(0.0087)\end{array}$ \\
\hline $\ln$ (TangibleAssets) & - & $\begin{array}{l}-0.0032 * * * \\
(0.0007)\end{array}$ & $\begin{array}{l}-0.0030 * * * \\
(0.0006)\end{array}$ \\
\hline $\ln ($ CompExp) & + & $\begin{array}{l}0.0016 \text { ** } \\
(0.0008)\end{array}$ & $\begin{array}{l}0.0017 \text { *** } \\
(0.0007)\end{array}$ \\
\hline IndustryROA & + & $\begin{array}{l}0.4909 * * * \\
(0.0343)\end{array}$ & $\begin{array}{l}0.4820 \text { *** } \\
(0.0335)\end{array}$ \\
\hline $\ln ($ Age $)$ & + & $\begin{array}{l}0.0110 * * * \\
(0.0019)\end{array}$ & $\begin{array}{l}0.0106 \text { *** } \\
(0.0020)\end{array}$ \\
\hline$\Delta \mathrm{GDP}$ & + & $\begin{array}{l}0.0793 * * * \\
(0.0190)\end{array}$ & $\begin{array}{l}0.0751 \text { *** } \\
(0.0189)\end{array}$ \\
\hline$\Delta$ MarketSize & + & $\begin{array}{r}-0.0002 \\
(0.0006)\end{array}$ & $\begin{array}{r}-0.0002 \\
(0.0008)\end{array}$ \\
\hline TaxIncentive & - & $\begin{array}{l}-0.0791 * * * \\
(0.0261)\end{array}$ & $\begin{array}{l}-0.0588 * * * \\
(0.0213)\end{array}$ \\
\hline Loss & - & $\begin{array}{l}-0.2483 * * * \\
(0.0062)\end{array}$ & $\begin{array}{l}-0.2490 * * * \\
(0.0063)\end{array}$ \\
\hline Loss*TaxIncentive & + & $\begin{array}{r}0.1918 * * \\
(0.0959)\end{array}$ & $\begin{array}{l}0.1503 \\
(0.0839)\end{array}$ \\
\hline HighSTR & $?$ & $\begin{array}{l}-0.0070 * * * \\
(0.0029)\end{array}$ & $\begin{array}{r}-0.0090 \\
(0.0079)\end{array}$ \\
\hline HighSTR*Loss & - & $\begin{array}{l}-0.0135 \\
(0.0171)\end{array}$ & $\begin{array}{l}-0.10611^{* * *} \\
(0.0326)\end{array}$ \\
\hline HighSTR*TaxIncentive & - & $\begin{array}{r}0.0464 \\
(0.0583)\end{array}$ & $\begin{array}{r}0.0726 \\
(0.1096)\end{array}$ \\
\hline $\begin{array}{l}\text { HighSTR*Loss*TaxIncentive } \\
\mathrm{N} \\
\text { adj. R-sq } \\
\text { Cluster }\end{array}$ & + & $\begin{array}{c}0.7074 * * \\
(0.3095) \\
56,087 \\
0.3062 \\
\text { Group }\end{array}$ & $\begin{array}{l}1.7213 * * * \\
(0.4267) \\
59.743 \\
0.3054 \\
\text { Group }\end{array}$ \\
\hline
\end{tabular}

This table estimates tests of $\mathrm{H} 2$ on the sample of 59,743 European affiliate-years 2003-2012 with at least one foreign affiliated firm also located in Europe and sufficient data from Amadeus and the European Commission for estimation in Column (2) as well as on the sample of 56,087 affiliates with sufficient data for estimation in Column (1). $\ln (R O A+1)$ is the natural $\log$ of ROA plus 1. ROA is EBIT scaled by Assets, where EBIT is earnings before interest and taxes and Assets is total assets. $\ln$ (TangibleAssets) is the natural $\log$ of total fixed assets. $\ln$ (CompExp) is the natural log of compensation expense. IndustryROA is a measure of country-year-industry median ROA. $\ln (A g e)$ is the natural $\log$ of Age, measured as year $t$ minus the year the affiliate first appears in the Amadeus database. $\triangle G D P$ is $G D P$ in year $t$ less GDP in year $t-1$, scaled by GDP in year $t-1$. $\triangle M$ MtSize is the country-industry-year sum of all affiliate and standalone firm sales in year $t$ less the sum in year $t-1$, scaled by $1,000,000$. TaxIncentive is $C$ in column (1) and STR in column (2). $C$ is a capitalweighted differential statutory tax rate between the affiliate and all related affiliates in the same group-year. STR is the meancentered country-year statutory tax rate. Loss is set to 1 if affiliate EBIT is less than zero. HighSTR is an indicator variable set to 1 if the affiliate's STR is in the top quartile by year. All specifications report standard errors clustered by group. *, $* *$, and $* * *$ represent one-tailed statistical significance at the $10 \%, 5 \%$, and $1 \%$ levels, respectively. 
Table 8: Tests of the Effect of Losses on the Affiliated Group
$\ln ($ ROA +1$)=\beta_{1}{ }^{*} \ln ($ TangibleAssets $)+\beta_{2} * \ln ($ CompExp $)+\beta_{3}{ }^{*}$ IndustryROA $+\beta_{4}{ }^{*}$ Shock $+\beta_{5}{ }^{*}$ TaxIncentive
$+\beta_{6} *$ AllProfit $+\beta_{7} *$ Loss $+\beta_{8} *$ ProfitWithLossAff $+\beta_{9} *$ Loss $*$ TaxIncentive + $\beta_{10} *$ ProfitWithLossAff*TaxIncentive

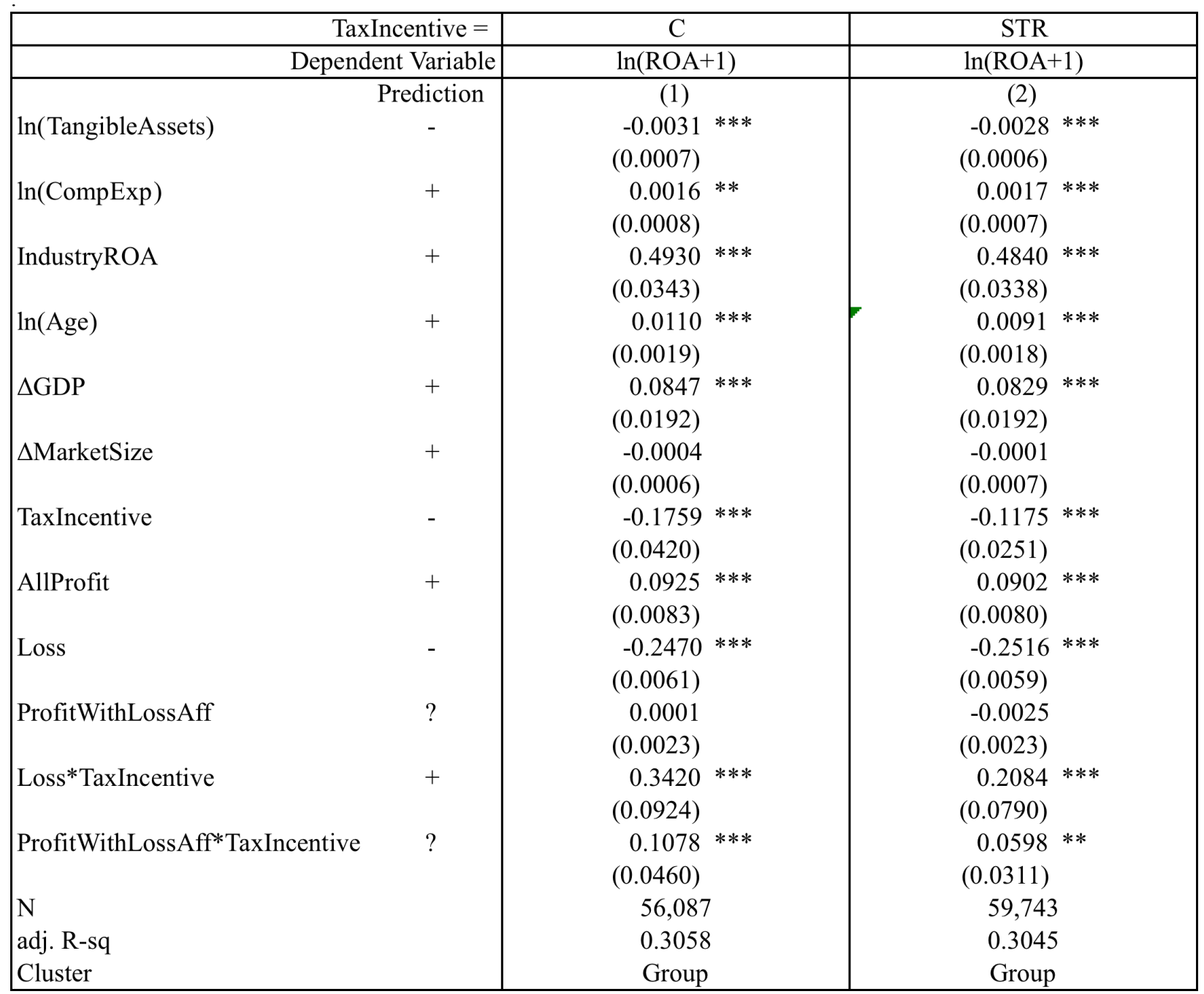

This table estimates the effect of losses on the affiliated group on the sample of 59,743 European affiliate-years 2003-2012 with at least one foreign affiliated firm also located in Europe and sufficient data from Amadeus and the European Commission for estimation in Column (2) as well as on the sample of 56,087 affiliates with sufficient data for estimation in Column (1). ). $\ln (R O A+1)$ is the natural $\log$ of $R O A$ plus 1 . ROA is EBIT scaled by Assets, where EBIT is earnings before interest and taxes and Assets is total assets. $\ln$ (TangibleAssets) is the natural log of total fixed assets. $\ln$ (CompExp) is the natural $\log$ of compensation expense. IndustryROA is a measure of country-year-industry median ROA. $\ln ($ Age) is the natural $\log$ of $A g e$, measured as year $t$ minus the year the affiliate first appears in the Amadeus database. $\triangle G D P$ is $G D P$ in year $t$ less $G D P$ in year $t-1$, scaled by GDP in year $t-1$. $\Delta M$ MtSize is the country-industry-year sum of all affiliate and standalone firm sales in year $t$ less the sum in year $t-1$, scaled by 1,000,000. TaxIncentive is $C$ in column (1) and STR in column (2). $C$ is a capital-weighted differential statutory tax rate between the affiliate and all related affiliates in the same group-year. STR is the mean-centered country-year statutory tax rate. AllProfit is an indicator variable set to 1 if all affiliates in the same multinational group-year have EBIT greater than or equal to zero. Loss is an indicator variable set to 1 if affiliate EBIT is less than zero. ProfitWithLossAff is an indicator variable set to 1 if affiliate EBIT is greater than or equal to zero but there is a related affiliated in the same multinational group-year with EBIT less than zero. We suppress the intercept when estimating these models. All specifications report standard errors clustered by group. $*, * *$, and $* * *$ represent onetailed statistical significance at the $10 \%, 5 \%$, and $1 \%$ levels, respectively. 